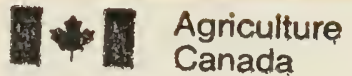

Canadian Agriculture Library

Bibliothèque canadienne de l'agriculture Ottawa K1A OC5

\title{
APPLE FRAMEWORKS AND ROOTSTOCKS IN BRITISH COLUMBIA
}

\author{
by \\ A. J. MANN \\ F. W. L. KEANE \\ and \\ K. LAPINS \\ Experimental Station \\ Summerland, B. C.
}

EXPERIMENTAL FARMS SERVICE 
Apple Frameworks

This bulletin describes experiments with hardy frameworks which have resulted in the recommendation of Canada Baldwin for this purpose.

\section{Apple Rootstocks}

Seedling rootstocks are recommended where a full sized tree is desired, and Malling II rootstock where a somewhat smaller tree is preferred. Malling IX stock will produce a true dwarf tree. The semi-dwarf rootstocks, Malling IV and Malling VII, are also discussed. 


\section{APPLE FRAMEWORKS AND ROOTSTOCKS IN BRITISH COLUMBIA}




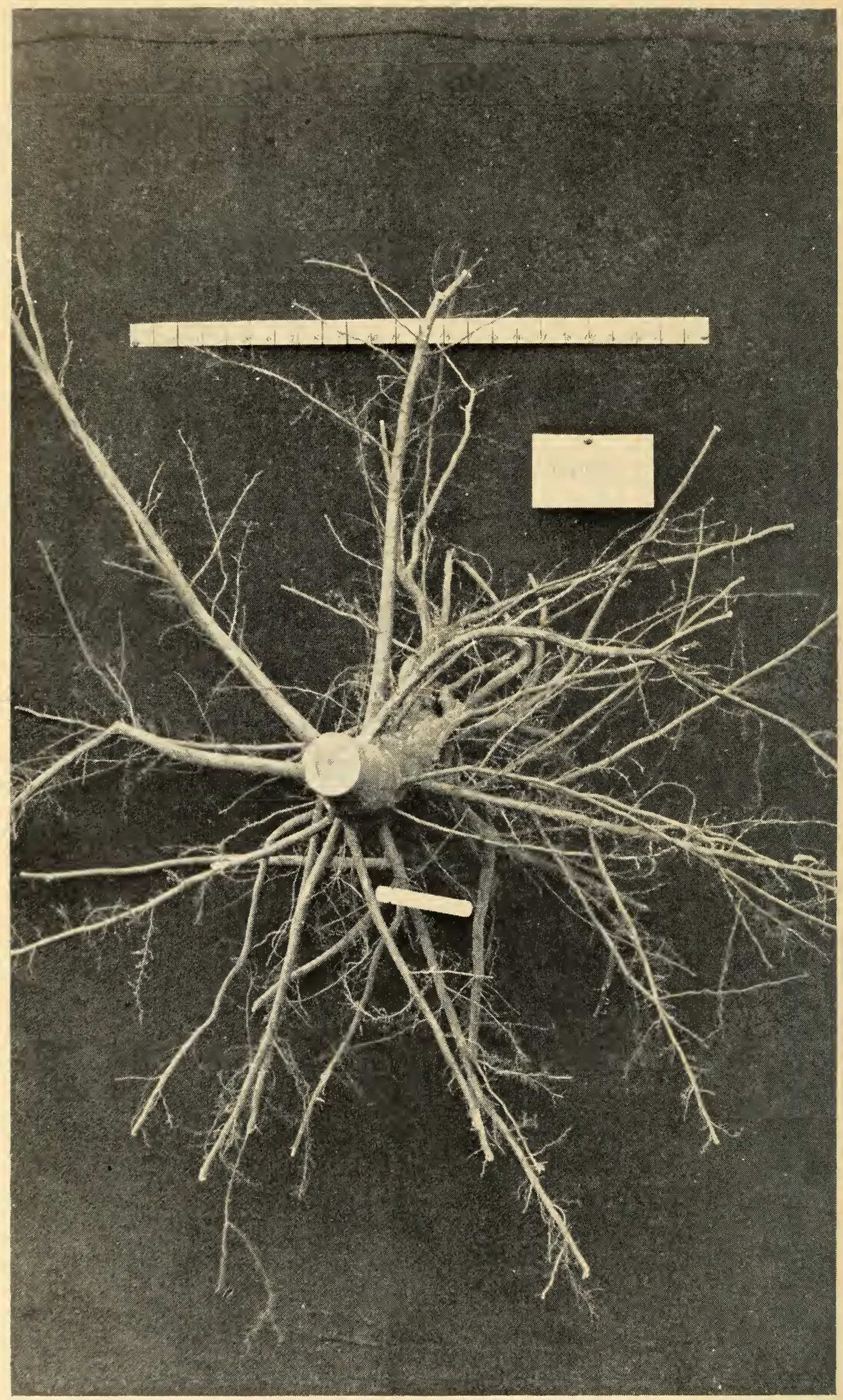

Frontispiece-Five-Year-Old Delicious Seedling Rootstock. 


\section{CONTENTS}

Part I-Frameworks $\quad$ Page

Introduction ............................. 7

Review of Literature......................... 8

Procedure with Framework Experiments in British Columbia...... 9

Results of Framework Experiments in British Columbia......... 11

Influence of Framework on Tree Size................. 11

Influence of Framework on Yield.................. 13

Compatibility of Framework and Scion Variety............ 15

Winter Hardiness of Single- and Double-Worked Trees... . . . . 18

Technique of Double-Working.................... 18

Characteristics of Framework Stocks................ 19

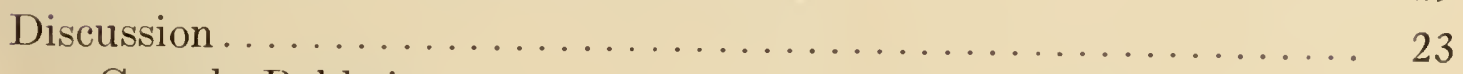

Canada Baldwin.............................. 25

McIntosh.............................. 25

Hibernal............................... 25

Virginia Crab............................ 25

Acknowledgments.............................. 26

References............................... 26

\section{Part II-Rootstocks}

Introduction ................................ 27

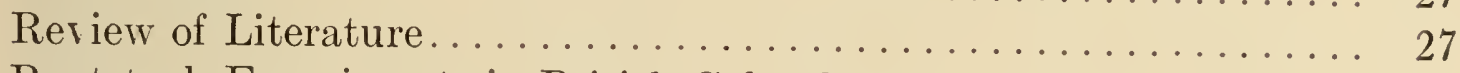

Rootstock Experiments in British Columbia.............. 30

Earlier Plantings at the Station................... 30

Orchard A............................. 30

Orchard B............................. 30

Orchard C........................... 30

Comparison of Yields, Orchards A, B and C.......... 32

Color and Storage Characteristics of the Fruit............ 34

Later Plantings of Malling Rootstocks at the Station........ 34

Seedling Rootstocks at the Station.................. 36

Crown Rot Tests by Inoculation................... 36

Growth Characteristics of Rootstocks............... 37

Hardiness of Rootstocks........................ 38

Discussion............................... 38

Acknowledgments............................ 39

References................................ 39 


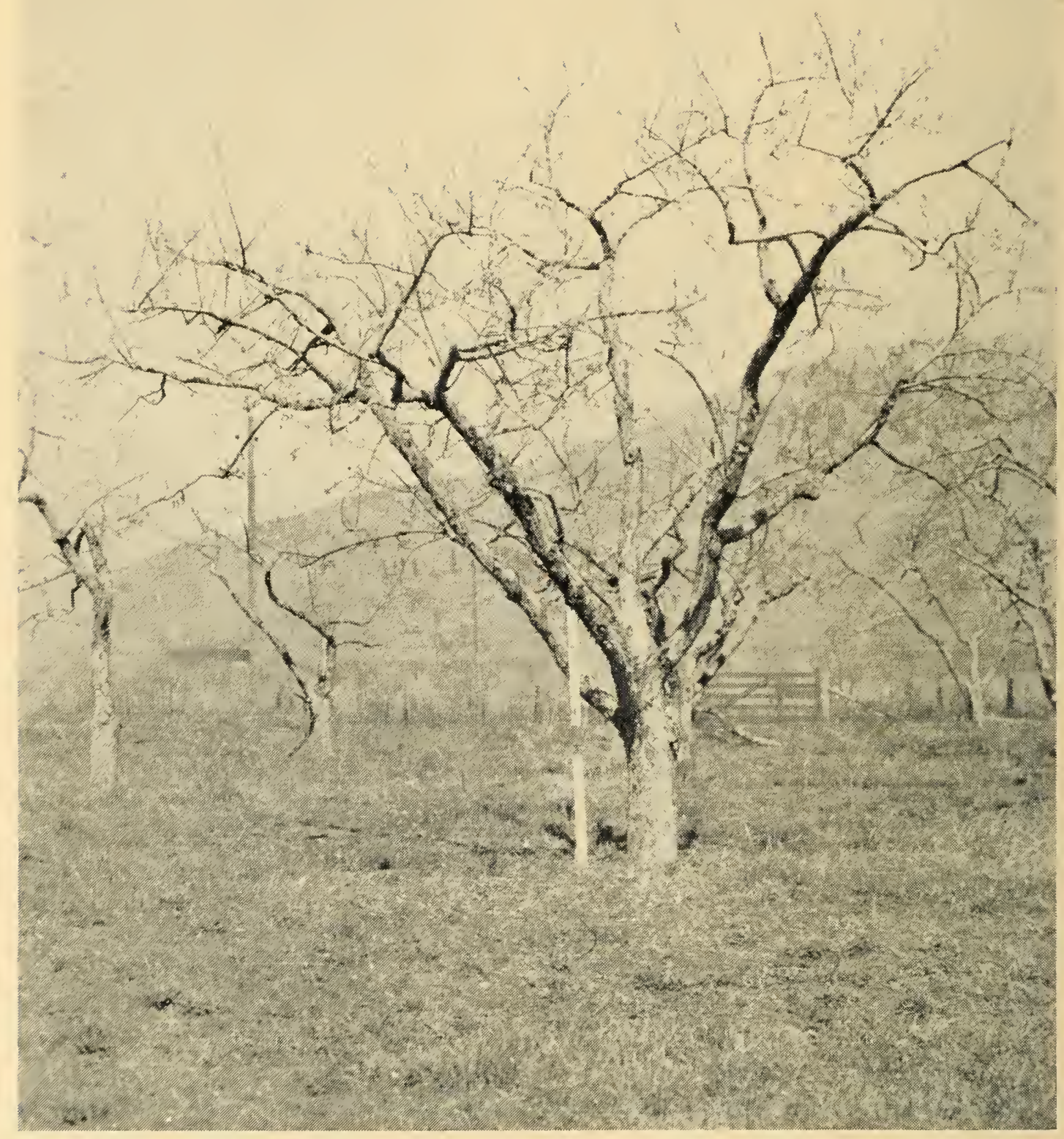

Figure 1.-A reteran of thirty-five winters. A healthy Jonathan on Canada Baldwin framework, Vernon, B.C., March, 1938. 


\section{PART I-FRAMEWORKS}

\section{INTRODUCTION}

Cultivated apple trees are composed of at least two parts: the rootstock and the scion variety. The usual procedure is to bud or graft the scion variety on the rootstock at or near ground level. Sometimes it is desirable to develop trees composed of three parts. Such trees are twice budded or grafted and are called double-worked trees, the trunk and main scaffold branches, referred to as the framework, being some hardy and disease-resistant variety. With such trees the rootstock is worked to the framework in the nursery and this in turn is worked to the desired commercial variety, usually in the second or third year from planting in the orchard.

The chief advantage claimed for double-worked trees, other than resistance to disease, is that they make possible the growing of relatively tender varieties, such as Delicious, Jonathan, Newtown, Rome Beauty and Stayman, in areas where winter conditions cause serious injury to these varieties when grown on their own frameworks (Fig. 1).

Notwithstanding the advantages claimed for double-working, there are horticulturists who doubt the advisability of this practice. The chief argument advanced is that there are adequate areas of land in North America and elsewhere, in which climatic conditions are sufficiently favorable for apple production to the full extent of market requirements, and therefore it is not necessary to resort to double-working in order to produce this fruit in less favored areas.

If apple production is to continue in the colder fruit-growing areas, it would seem that the double-working of relatively tender varieties should be considered only as a temporary expedient. Taking the long range view, the ultimate objective lies in breeding superior varieties of sufficient hardiness to thrive under adverse climatic conditions. In the meantime, double-working of apple trees is practised extensively in various areas where winter injury to trunks and frameworks is prevalent.

The general characteristics sought in satisfactory framework stocks are: hardiness; compatibility with commercial varieties; tough tissues to withstand wind; fairly upright habit; sufficient rigidity to avoid undue drooping of branches; reasonably wide-angled crotches to resist mechanical splitting and favor early ripening of tissues in that area; strong, well-balanced scaffold branches, capable of supporting heavy crops without breakage; resistance to diseases such as crown rot, perennial canker, anthracnose and fire blight.

During the early development of apple production in the northern Okanagan, occasional severe winters caused extensive injury to apple trees of certain varieties then being grown (Fig. 2). Realizing the possibility of similar winter conditions and tree injury recurring periodically, district horticulturists conducted a survey of the hardiness of the apple varieties in the area. The information gathered indicated that a number of varieties were considered resistant to injury from severe winter conditions. These varieties were Red Astrachan, Canada Baldwin, Duchess, McIntosh, Snow, Wealthy and Winter St. Lawrence. Attention was given then to their suitability as stocks for double-working. In due course Canada Baldwin was selected, this variety being considered outstanding for hardiness and for soundness of wood in old trees. 


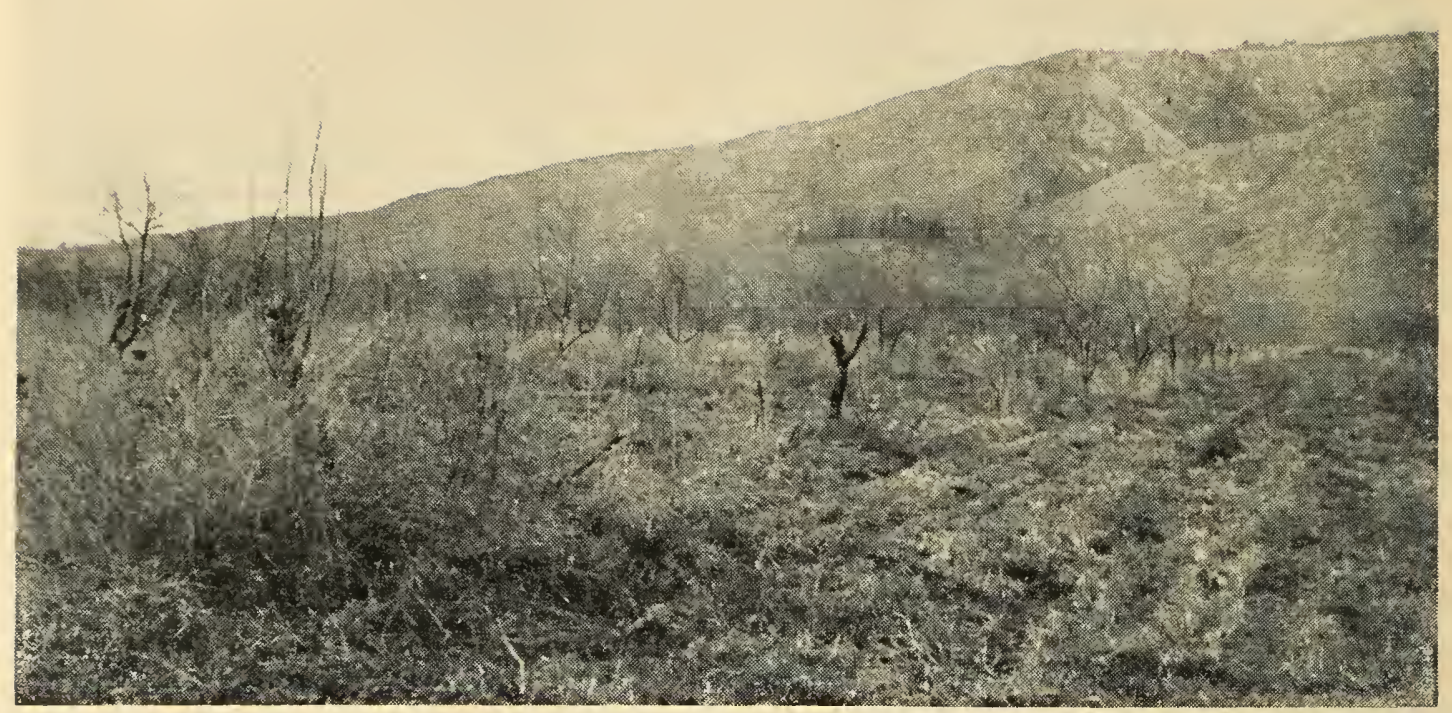

Figure 2.- Showing the ravages of winter injury in an orchard of Rome Beauty and Delicious in a northern area, 1938.

Thus, in the northern Okanagan, the double-working of relatively tender varieties of apple began about 1926, following the severe winter of 1924-25. By 1935, approximately 29,000 trees had been double-worked, the framework chiefly used for the purpose being Canada Baldwin. Notwithstanding the desirable characteristics of Canada Baldwin, there was some loss of trees when this variety was used as a framework. Research conducted by the Laboratory of Plant Pathology, Summerland, revealed that this loss of trees was due to the susceptibility of Canada Baldwin to crown rot, a disease caused by Phytophthora cactorum.

In 1935-36 another very severe winter occurred, causing serious and extensive damage to apple trees. It was noted that even McIntosh, a relatively hardy variety, was injured in trunk and framework. It was also noted that the later varieties Delicious, Jonathan, Newtown, Rome Beauty and Stayman were even more susceptible than McIntosh to winter injury. Thus it became evident that further investigations should be conducted into the potentialities of doubleworking tender varieties. Accordingly, in 1936, the Summerland Experimental Station made preparations for large trial plantings of a wide variety of hardy framework stocks. These plantings were designed to determine to what extent winter injury to apple trees could be prevented by the use of hardy frameworks, and further, to ascertain the most satisfactory frameworks for the commercial varieties grown extensively in the Okanagan and adjacent valleys.

\section{REVIEW OF LITERATURE}

Research workers and fruit growers are unanimous in the opinion that the hazards of winter injury in orchards can be lessened by the use of hardy frameworks. Hardiness and compatibility with the scion variety are considered to be the most important features in a desirable framework stock. 
Blair (2) reported that records at Ottawa dating from 1890 showed Hibernal, Charlamoff, Antonovka and Anis to be outstanding in hardiness, compared with McIntosh. Later, Hibernal, Antonovka, Osman, Columbia and Malus robusta No. 5 were recommended as the most promising frameworks stocks (Davis, Blair and Cannon, 4). Blair (3) has indicated that Malus robusta No. 5 stools readily and upon removal from the stool bed can be lined out in the nursery and subsequently planted in the orchard without the added expense of budding.

Filewicz and Modlibowska (5) reported that in Poland, where winter temperatures of $-40^{\circ} \mathrm{F}$. were commonly experienced, Antonovka was one of the varieties most resistant to winter injury. Later, in the same country, the varieties Antonovka, Hibernal, Fredowka and Ananas Berzenicki were recommended as frameworks (Maurer, 11).

Talbert (15) considered that, for Missouri conditions, Virginia should be used for the varieties Rome Beauty and Jonathan, while Stayman gives better results on Hibernal stocks. Delicious produces equally well on Virginia and Hibernal.

Alderman (1) noted that in Minnesota Hibernal had been generally used and was considered perhaps the nearest approach to the best all-round stock.

Overley (14) made a survey of frameworks in Iowa and concluded that Hibernal was the most desirable stock. He states that if planted with the graft 4 inches below ground level, Hibernal will develop its own winter-hardy root system. He mentions that the only possible shortcoming in Hibernal is that its wood seems to be slightly brittle.

Maney and Plagge (10) considered Virginia, Hibernal, Haas and possibly Sheriff as being iramework stocks well adapted to Iowa conditions. Later, in 1937, Maney (9) reported that Virginia gave somewhat peculiar reactions with different varieties, and that with some varieties of the Winesap group it acted as a dwarfing stock. Since then, evidence has accumulated that Virginia may show incompatibility or dwarfing effect in combination with some varieties, e.g. Stayman and McIntosh, or at least with some strains of these varieties (Hewetson, 6, McClintock, 12, 13, Tukey and Brase, 16, Hilkenbaeumer, 8).

\section{PROCEDURE WITH FRAMEWORK EXPERIMENTS IN BRITISH COLUMBIA}

Propagating material of the following varieties was obtained from experiment stations in Iowa, Manitoba and Ontario, and from local sources: Antonovka, Atlas, Beauty Crab*, Bedford Crab, Canada Baldwin, Charlamoff, Columbia Crab, Dolgo Crab, Florence Crab, Haralson, Haas, Hibernal, Hyslop Crab, Lobo, Malus baccata, McIntosh, Melba, Olga Crab, Osman Crab, Pioneer Crab, Robin Crab, Sheriff, Tony Crab, Transcendent Crab, Virginia Crab, Winter St. Lawrence and Wolf River. Over 13,000 trees of these varieties were raised on known rootstocks in the nursery at the Summerland Experimental Station.

Using some of the above trees, a two-acre orchard was planted on the Station in 1938 and top-worked in 1940 and 1941. A site was selected on a gently sloping bench of shallow sandy loam soil underlaid with gravel. Culture with respect to pruning, thinning, spraying, fertilizing and soil management was similar to that practised in many commercial orchards in the Okanagan Valley.

*For the sake of brevity the word "Crab" is omitted from the names of crabapples in most sections of this bulletin. 
The frameworks used in this orchard were Antonovka, Canada Baldwin, Charlamoff, Hibernal, McIntosh, Melba, Osman, Virginia and Winter St. Lawrence. Ten trees of each of these frameworks were worked on Malling XVI rootstocks and ten on open pollinated seedlings of McIntosh. Two trees of each rootstock-framework combination were later worked to each of the following varieties: Delicious, Jonathan, Newtown, Stayman and Winesap. The planting also included two trees of each of these varieties worked on the same rootstocks but grown with their own frameworks.

The orchard was originally planted on the randomized block system, with the trees $30 \times 15$ feet apart, but in the autumn of 1947 all the trees on McIntosh seedling rootstock were removed, leaving the trees on Malling XVI rootstock $30 \times 30$ feet apart.

With the co-operation of horticulturists of the British Columbia Department of Agriculture, over 12,000 trees, representing various rootstock-framework combinations, were placed in the orchards of growers located in 13 districts. Care was taken to place most of the trees in areas where there had been serious trunk and framework injury to commercial varieties. The major plantings took place during 1939, 1940 and 1941.

All the trees were grown in the orchards for two or three years prior to double-working. During these years pruning consisted of the selection and development of suitable scaffold branches, in accordance with the potentialities of the framework variety. The scion variety was budded or grafted on the framework branches at approximately 18 inches or more from the trunk, in order to take advantage of the hardy scaffold. In the subsequent pruning of the double-worked trees it was found desirable to retain the central leader to a height of 8 to 10 feet in order to give structural strength to the tree.

An experiment was initiated in 1938 to test frameworks for susceptibility to crown rot. These tests were conducted on the Summerland Experimental Station in co-operation with the Summerland Laboratory of Plant Pathology. Framework varieties were inoculated with the organism and the extent of resulting infection provided information as to their susceptibility. This information is presented in the section dealing with the characteristics of each framework.

Yields of fruit produced by the trees on the Station were recorded each year. Growth measurements and studies of the compatibility of scion and framework were made periodically on these trees and also on large numbers of trees in growers' orchards.

During the period 1939 to 1949 , while the orchards were becoming established and beginning to crop, the winters were relatively mild and there was little opportunity to observe the responses of the various framework-scion combinations under severe weather conditions. However in 1949-50 the coldest winter on record occurred. Temperatures from $-30^{\circ} \mathrm{F}$. to $-40^{\circ} \mathrm{F}$. were experienced in Kamloops, Salmon Arm and Vernon. This afforded an opportunity of observing the effect of prolonged extremely low temperatures on the trees, then about ten years of age and mostly worked to Delicious.

Plantings of clonal Malus robusta No. 5 as a combined rootstock and framework were added to the experiment in 1951, both on the Station and in growers' orchards. 


\section{RESULTS OF FRAMEWORK EXPERIMENTS IN BRITISH COLUMBIA}

\section{Influence of Framework on Tree Size}

The trunk circumference was measured at about one foot from ground level, and the size of each tree, as indicated by cross-sectional area, was determined. To facilitate comparison, relative size was calculated, using trees with Canada Baldwin framework as a base at 100. Relative size of trees with various frameworks is shown in Table 1.

\section{TABLE 1. EFFECT ON FRAMEWORK ON TREE SIZE-EXPERIMENTAL STATION ORCHARD.}

\begin{tabular}{|c|c|c|c|}
\hline \multirow{3}{*}{ Framework } & \multicolumn{3}{|c|}{ Relative Trunk Cross-Sectional Area* } \\
\hline & $\begin{array}{l}\text { On McIntosh } \\
\text { Seedling } \\
\text { Rootstock }\end{array}$ & On Malling $\mathrm{X}$ & VI Rootstock \\
\hline & 1942 (5 years) & 1942 (5 years) & 1951 (14 years) \\
\hline 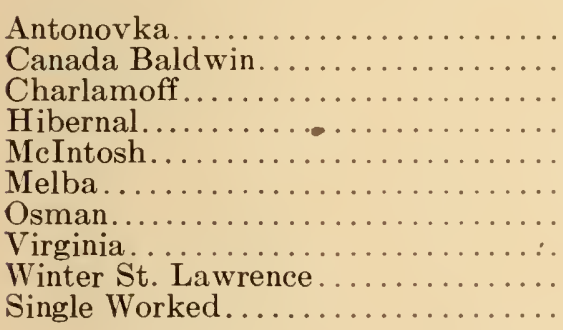 & $\begin{array}{r}56 \\
100 \\
70 \\
68 \\
127 \\
106 \\
66 \\
164 \\
87 \\
109\end{array}$ & $\begin{array}{r}83 \\
100 \\
94 \\
91 \\
105 \\
91 \\
83 \\
158 \\
93 \\
155\end{array}$ & $\begin{array}{r}90 \\
100 \\
78 \\
85 \\
96 \\
76 \\
82 \\
74 \\
101 \\
120\end{array}$ \\
\hline
\end{tabular}

* Calculated from at least 7 , and in most cases 9 or 10, trees of each rootstock-framework combination, the scion varieties being 1 or 2 trees each of Delicious, Jonathan, Newtown, Stayman and Winesap.

The actual tree measurements, from which Table 1 was compiled, showed no consistent difference in size of the trees on McIntosh seedlings compared with those on Malling XVI rootstock at 5 years of age. On the other hand, the framework exerted a marked influence on tree size. At 5 years of age Virginia had produced the largest trees on both rootstocks, whereas Antonorka and Osman gave comparatively small trees.

By the time the trees reached 14 years of age those with Virginia framework were the smallest, indicating a dwarfing effect as the trees grew older. Charlamoff and Melba had also tended to exert a slightly dwarfing influence. The singleworked trees were comparatively large at both 5 and 14 years of age. This may have been due in part to the fact that these trees were not cut back at the time the double-worked trees were cut back after budding. 
To indicate the influence which frameworks had on the growth of the trees located in the orchards of co-operating growers, data recorded in 5 representative orchards, when the trees were 10 to 11 years old, are presented in Table 2.

TABLE 2. INFLUENCE OF FRAMEWORK ON TREE SIZE-GROWERS' ORCHARDS.

\begin{tabular}{|c|c|c|c|c|}
\hline Framework & Seedling Rootstock & $\begin{array}{c}\text { Number } \\
\text { of } \\
\text { trees }\end{array}$ & $\begin{array}{l}\text { Age } \\
\text { of } \\
\text { trees }\end{array}$ & $\begin{array}{l}\text { Average } \\
\text { trunk } \\
\text { cross- } \\
\text { sectional } \\
\text { area }\end{array}$ \\
\hline & & & years & sq. in. \\
\hline
\end{tabular}

Orchard No. 1, Kamloops-Variety Delicious

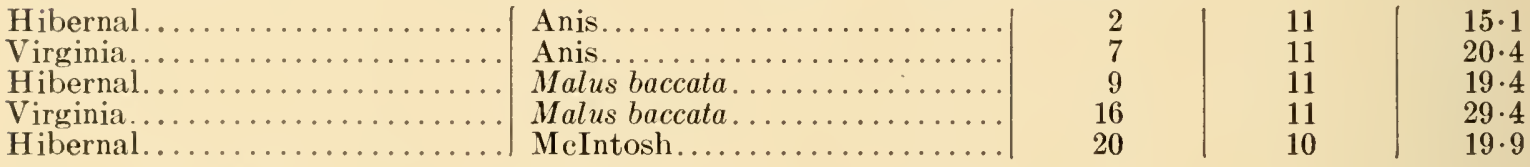

Orchard No. 2, Salmon Arm-Variety Delicious

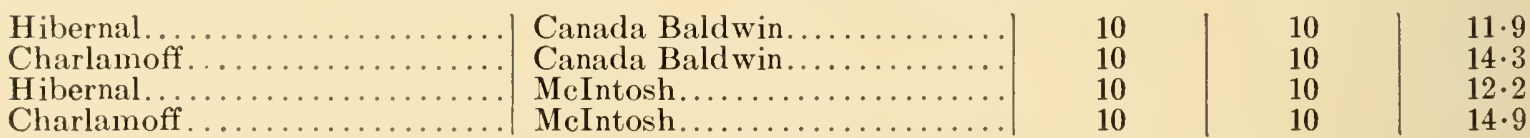

Orchard No. 3, Vernon-Variety Jubilee

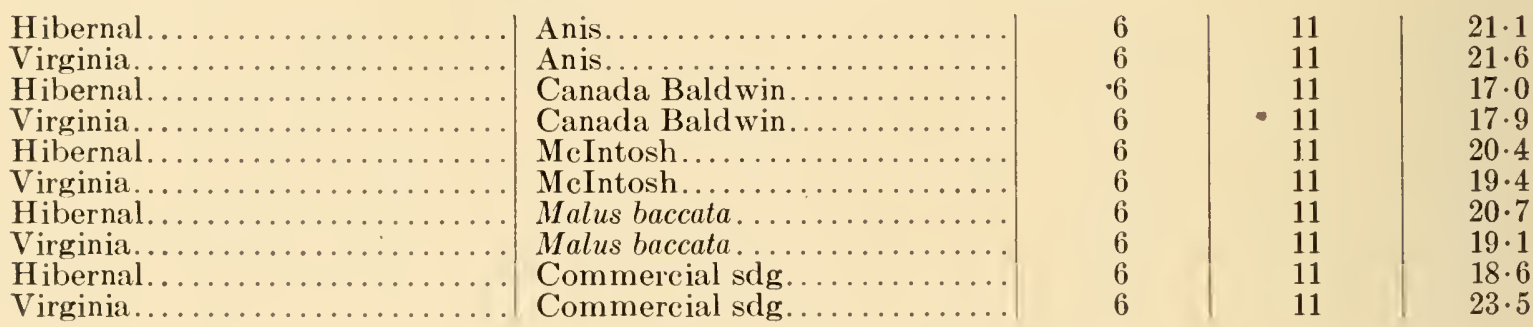

Orchard No. 4, Vernon-Variety Spartan

Hibernal.................. MeIntosh................

Virginia.....................

Orchard No. 5, Kelowna-Variety Spartan

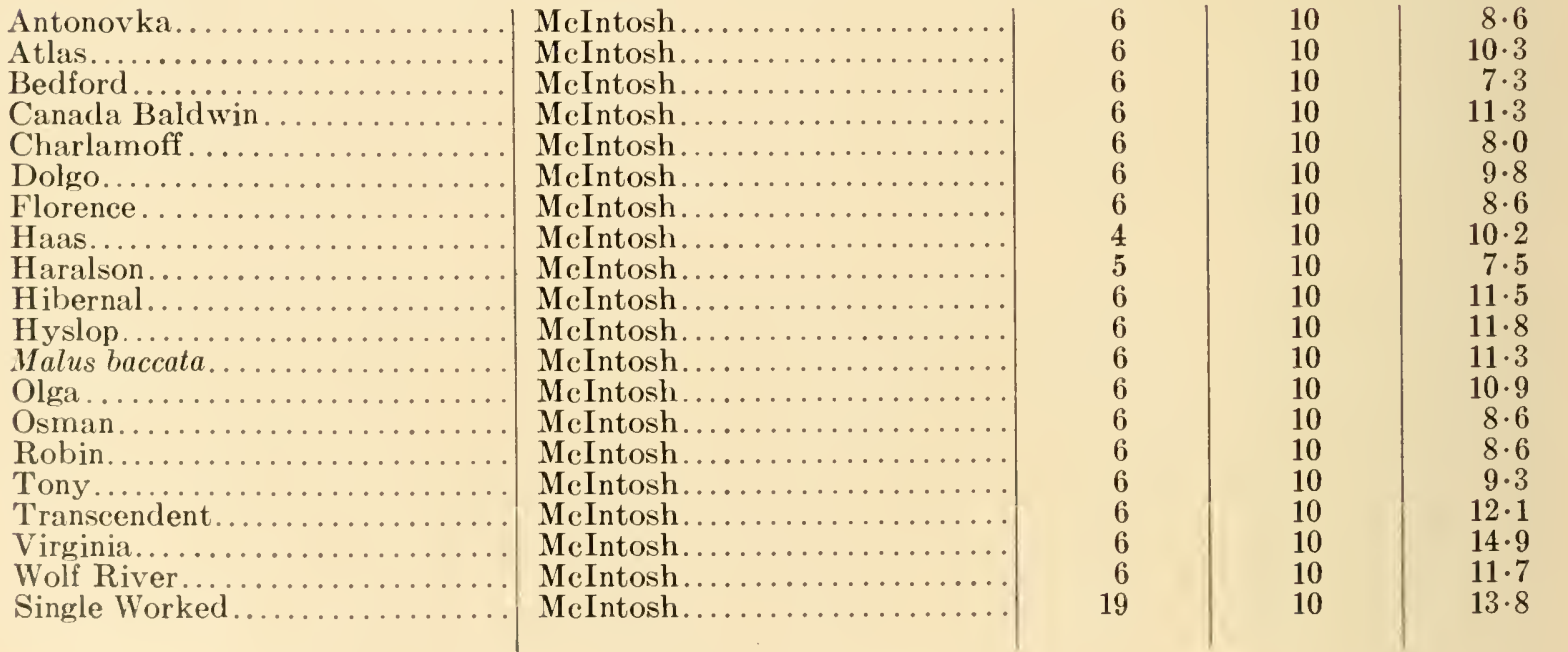


In general, the findings in the various orchards indicate that, where trees were double-worked, there was no consistent tendency for any one rootstock to produce larger trees than any other rootstock.

With respect to the influence of framework on tree size, the data in Table 2 reveal that in Orchards 1, 3, 4 and 5 Hibernal had mostly produced smaller trees than Virginia at 10 to 11 years of age. Similarly the data for Orchard 2 indicate that at 10 years of age trees with Hibernal frameworks were smaller than those with Charlamoff frameworks. The information presented for Orchard 5 suggests that the use of Antonovka, Bedford, Charlamoff, Dolgo, Florence, Haralson, Osman, Robin and Tony as frameworks may have had some dwarfing influence. However, the number of trees involved was small.

\section{Influence of Framework on Yield}

The total yield produced by each of the trees in the Station orchard was recorded in pounds each year. To facilitate comparison, relative yields have been calculated, using trees with Canada Baldwin frameworks as a base at 100 . The relative cumulative yield produced over 10 - and 14-year periods by the trees with each rootstock-framework combination is shown in Table 3.

TABLE 3.-INFLUENCE OF FRAMEWORK ON YIELD-EXPERIMENTAL STATION ORCHARD.

\begin{tabular}{|c|c|c|c|}
\hline \multirow{3}{*}{ Framework } & \multicolumn{3}{|c|}{ Relative Cumulative Yield per Tree* } \\
\hline & $\begin{array}{c}\text { On McIntosh } \\
\text { Seedling } \\
\text { Rootstock }\end{array}$ & \multicolumn{2}{|c|}{ On Malling XVI Rootstock } \\
\hline & $\begin{array}{c}1938-47 \\
(10 \text { years })\end{array}$ & $\begin{array}{c}1938-47 \\
(10 \text { years })\end{array}$ & $\begin{array}{c}1938-51 \\
\text { (14 years) }\end{array}$ \\
\hline$\ldots \ldots \ldots \ldots \ldots \ldots \ldots \ldots \ldots \ldots \ldots$ & 92 & 113 & 108 \\
\hline 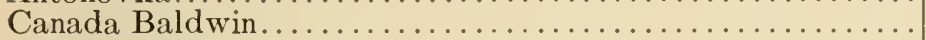 & 100 & 100 & 100 \\
\hline 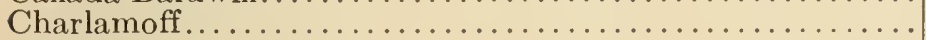 & 209 & 216 & 125 \\
\hline 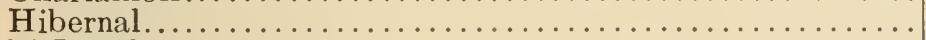 & 156 & 146 & 121 \\
\hline 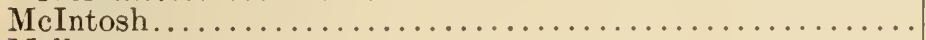 & 122 & 205 & 129 \\
\hline 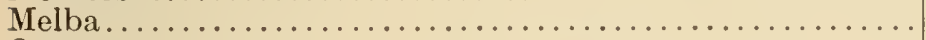 & 242 & 129 & 108 \\
\hline 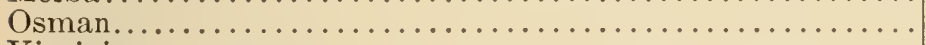 & 113 & 111 & 115 \\
\hline 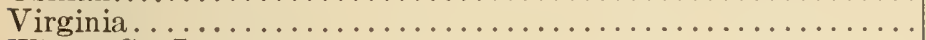 & 402 & 321 & 126 \\
\hline 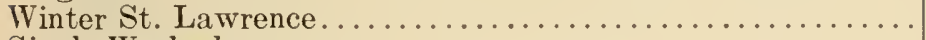 & 83 & 114 & 101 \\
\hline 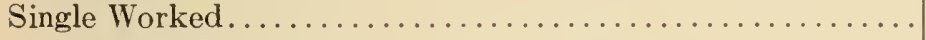 & 383 & 310 & 136 \\
\hline
\end{tabular}

* Calculated from at least 7 and in most instances 9 or 10 trees of each rootstock-framework combination, the scion varieties being 1 or 2 trees each of Delicious, Jonathan, Newtown, Stayman and Winesap.

It will be noted from Table 3 that at 10 years of age the trees with Virginia frameworks had given the highest average yield. Next in order were the singleworked trees, followed by those with Charlamoff framework. Trees with Melba, Hibernal and McIntosh frameworks had produced medium crops, whereas those with Antonovka, Canada Baldwin and Winter St. Lawrence frameworks had given comparatively low yields.

At 14 years from planting the order with respect to ricld had changed slightly. The highest yields were produced by the single-worked trees. Next in order were trees with McIntosh, Virginia and Charlamoff frameworks. The trees with Winter St. Lawrence and Canada Baldwin frameworks gave the lowest yields. There was much less difference in yield between the trees with the different frameworks at 14 than at 10 years of age. 


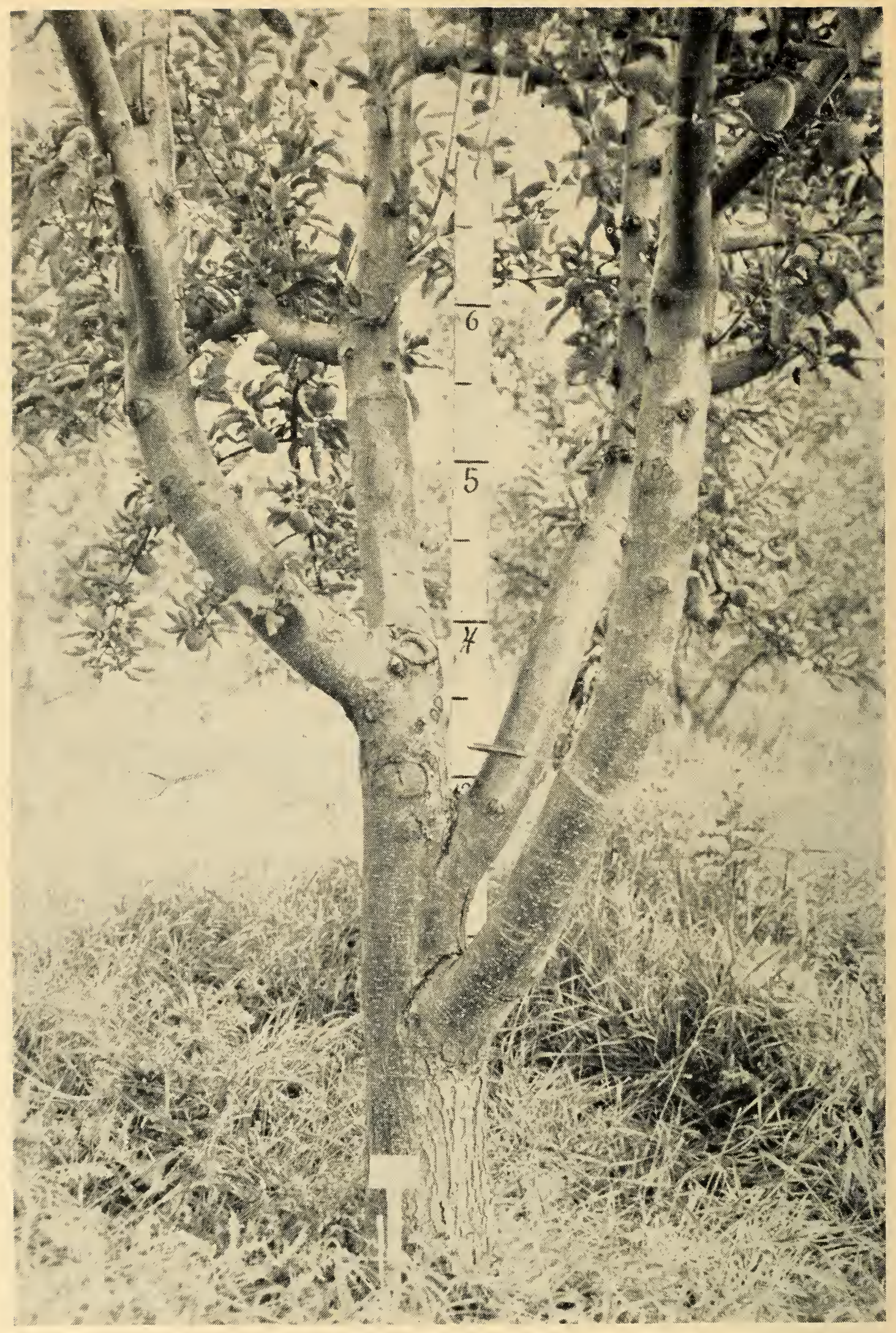

Figure 3.-Delicious on Canadia Baldwin framework at thirteen years from planting and ten year's from top-working. Summerland, B.C., September, 1951.

In relation to size at 14 years of age, the trees on Virginia and Charlamoff had produced the highest yields; trees on Canada Baldwin and Winter St. Lawrence had produced the lowest yields, while yields of the single-worked trees were also low. 


\section{Compatibility of Framework and Scion Variety}

Compatibility was evaluated on the basis of smoothness of the union and uniformity of growth below and above the union. Frameworks and scion varieties were considered compatible when they made smooth unions and produced growth approximately equal below and above the union. (Fig. 3).

The various framework-scion combinations were given a compatibility score value from 1 (lowest) to 10 (highest). Scores for each combination, in Station and growers' orchards, are presented in Table 4.

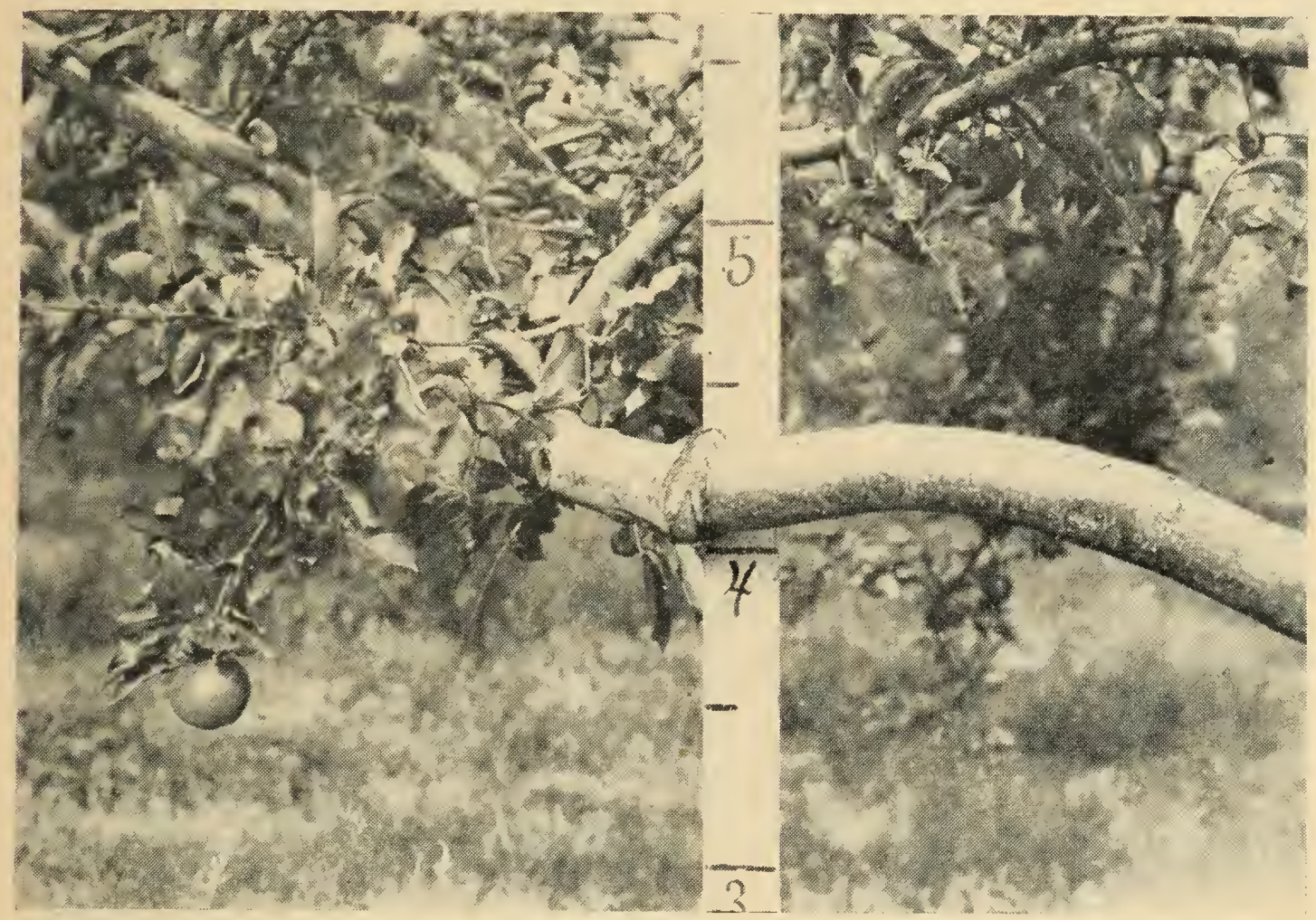

Figure 4.- Showing bulge at union of Stayman and Virginia Crab framework at ten years from top-working. Summerland, B.C., September, 1951. 


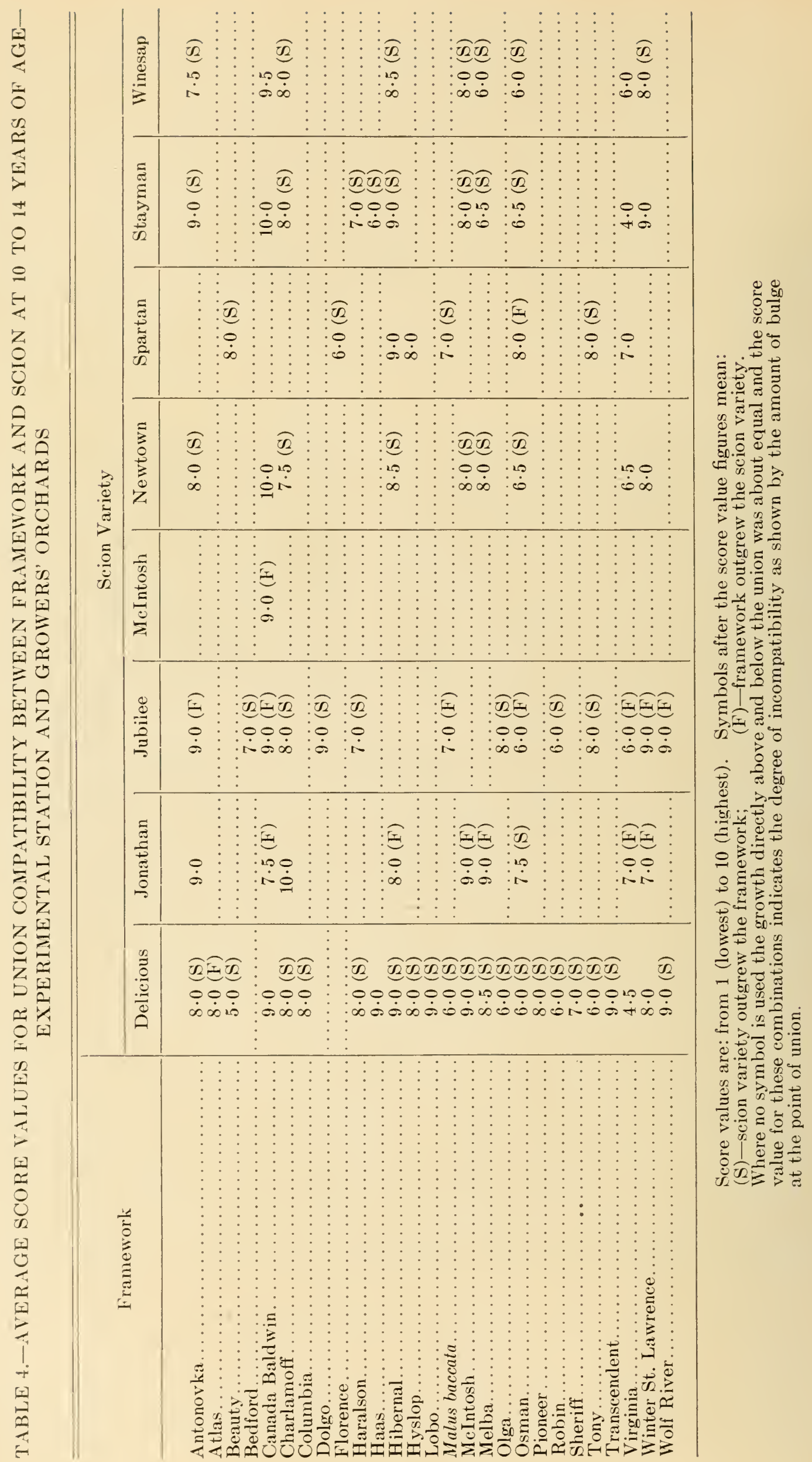




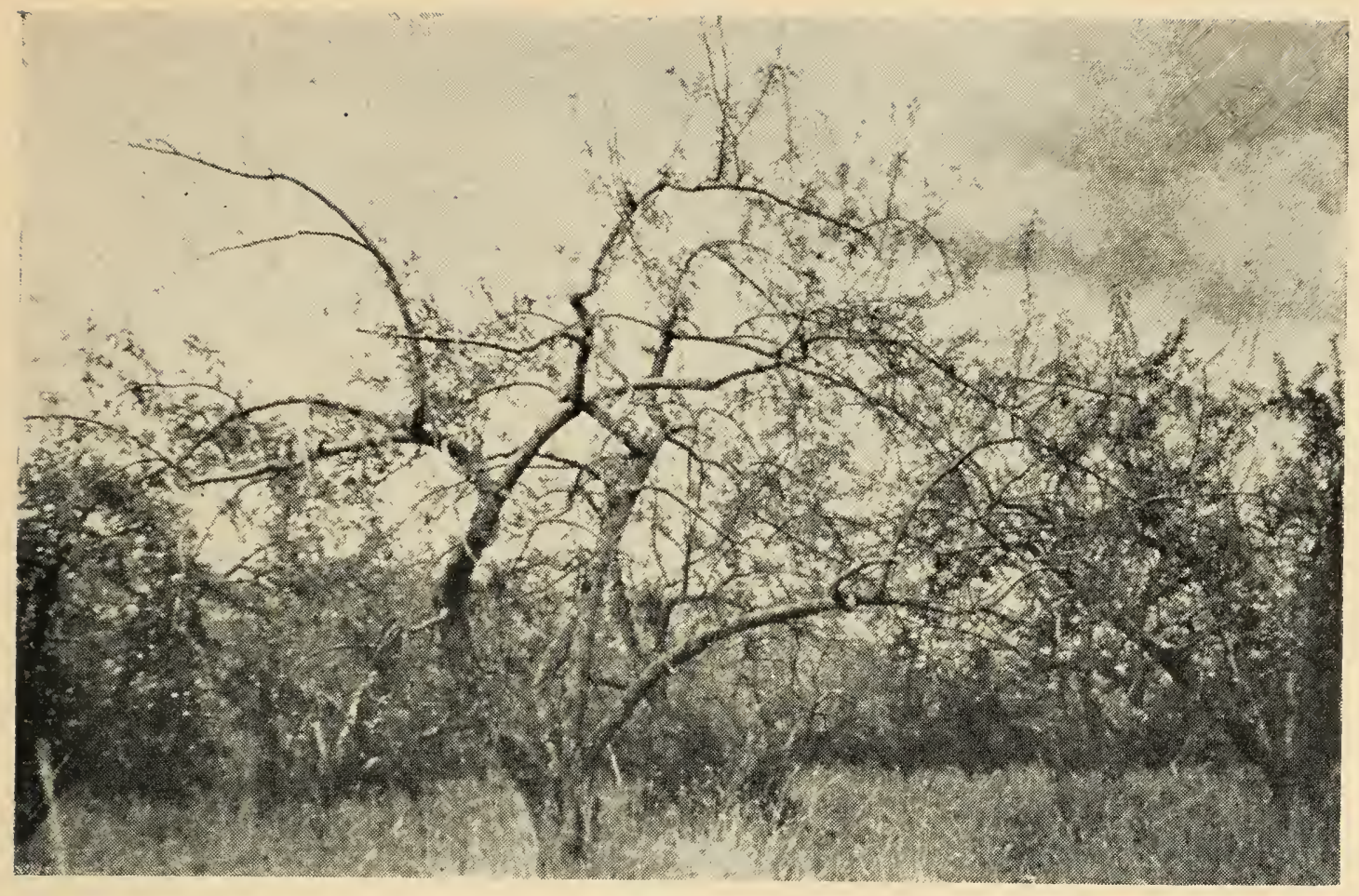

Figure 5.-Delicious on own framework, showing very sparse foliage, due to severe winter injury to trunk and limbs. Salmon Arm, B.C., August, 1950.

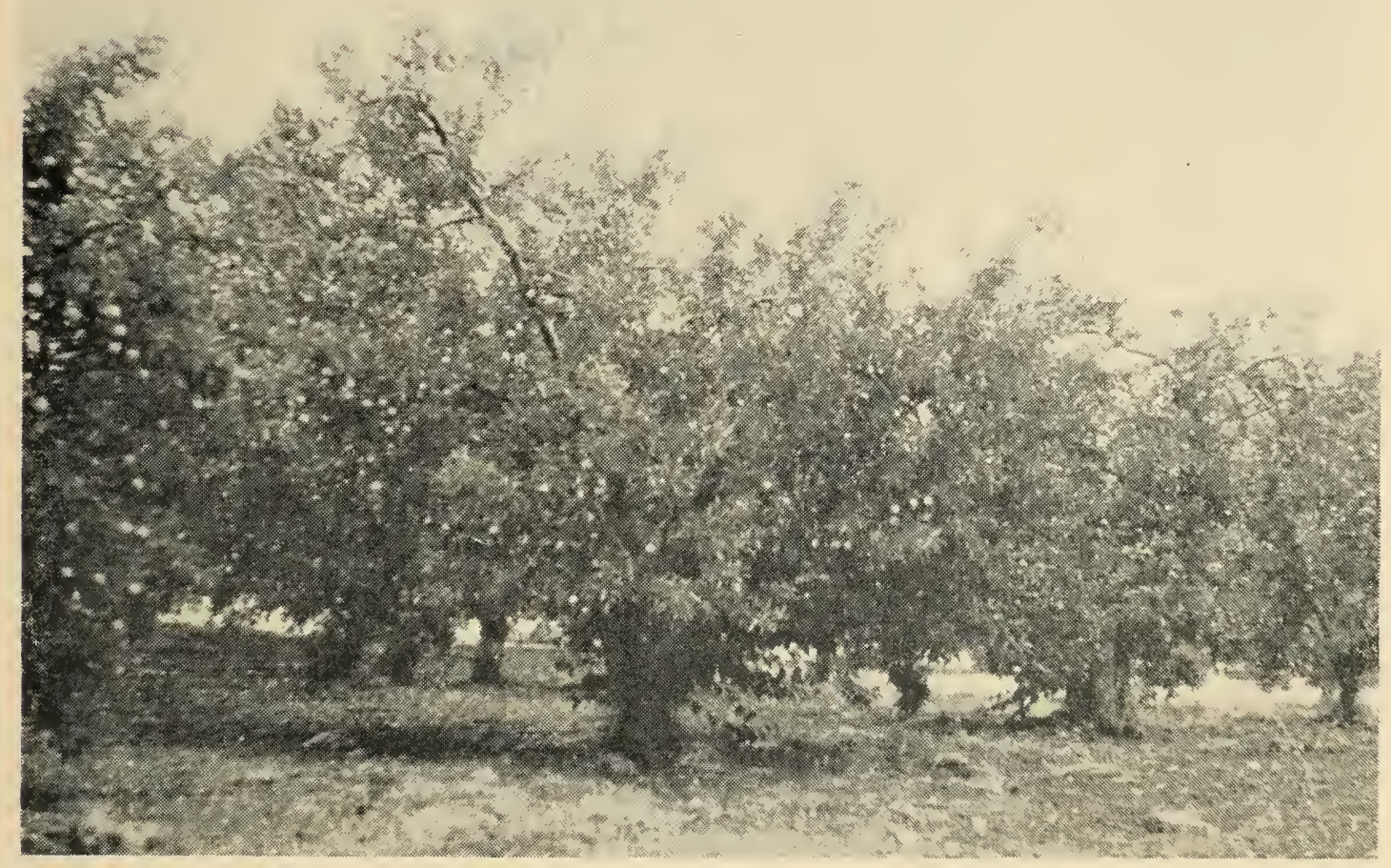

Figure 6.-Delicious on Transcendent Crab framework, showing tree in full foliage, with no winter injury. Salmon Arm, B.C., August, 1950. 
The data shown in Table 4 reveal that Delicious, Jonathan, Jubilee, McIntosh. Newtown, Spartan, Stayman and Winesap all made good unions with Canada Baldwin, Hibernal and Winter St. Lawrence frameworks. Delicious, Jonathan, Newtown, Stayman and Winesap all made good unions with McIntosh frameworks. Antonorka and Charlamoff appeared to be less compatible with Winesap and Newtown, respectively, than were the above frameworks.

Poor compatibility, at least with some scion varieties, was shown by Melba, Osman and Virginia (Fig. 4). With a few exceptions, crabapple frameworks appeared to show rather poor compatibility with the scion varieties.

In combinations with Jonathan, the framework in most instances outgrew the scion, whereas the other scion varieties, except Jubilee, usually outgrew the framework. Jubilee showed no definite tendency in either direction.

\section{Winter Hardiness of Single- and Double-Worked Trees}

Thousands of Delicious trees on their own frameworks were killed or severely damaged by the low temperatures experienced during the winter of 1949-50. In many instances, adjacent Delicious trees of the same age, topworked on hardy frameworks, survived without material injury (Figs. 5 and 6). However, in some orchards severe injury was experienced in the bearing area of Delicious trees, even though they were top-worked on hardy frameworks. The severity of the injury was influenced by such factors as age of tree and amount of previous crop, as well as by temperature conditions. The results indicate, however, that when temperatures lower than $-30^{\circ} \mathrm{F}$. are experienced, winter injury to the bearing wood of Delicious is likely to be extensive, regardless of the use of hardy framework stocks.

Hilborn and Waring (7) report on the possibility that a variety which is tender in itself may be rendered more cold resistant by double-working it on a hardy framework. Field observations on Delicious trees in British Columbia have not supported this possibility. In some instances after-effects, causing death of twigs and limbs, occurred in Delicious tops when the trunk and framework had been severely injured. To this extent a hardy framework might be said to exert an indirect influence on top injury. There was however, no evidence that the actual winter injury to the Delicious top was more severe on a tender trunk and framework than on a hardy trunk and framework.

The severe winter of 1949-50 revealed that the varieties McIntosh, Melba and Winter St. Lawrence were only moderately hardy when used as framework stocks. In that winter all the other stocks under test proved capable of withstanding very low temperatures without injury, and it was not possible to distinguish between them any fine differences in relative hardiness. However, owing to the fact that resistance to winter injury is influenced not only by temperature but also by other factors, it cannot be assumed that these stocks will never experience winter damage under British Columbia conditions.

\section{Technique of Double-Working}

Observations of double-worked trees on the Station and in growers' orchards showed satisfactory results where the frameworks were budded in the second year from planting or grafted in the spring of the third year. At that time there was usually satisfactory branch formation. Desirable trees resulted from the selection of a leader and three or four scaffold branches with strongly formed crotches. It was usually found advisable to retain permanently the central learler of the double-worked tree, a modified leader form being eventually developed. With frameworks such as Canada Baldwin and McIntosh, 
which are mechanically strong and not subject to breakage, satisfactory results were secured by double-working the scaffold branches at about 18 to 24 inches from the trunk. Such distances, however, appeared to be too great with Hibernal and crabapple frameworks and in some instances splitting, twisting and breakage occurred.

\section{Characteristics of Framework Stocks}

The following brief descriptions have been prepared from the results secured in both Station and growers' orchards.

The symbols A, B, C and D at the beginning of the description of each framework refer to the number of trees on which the findings are based.

A indicates a large number of trees permitting reliable findings.

$B$ indicates a lesser number of trees insufficient to permit a general commercial recommendation.

$\mathrm{C}$ indicates a rather small number of trees and the findings are consequently less reliable.

$\mathrm{D}$ indicates very few trees and the findings should be accepted only as an indication of the results which may be expected.

Antonovka: (Russia): (B). Hardy; crotches rather narrow-angled but strong; made relatively smooth unions with Delicious, Jonathan, Jubilee, Newtown and Stayman, but slightly less smooth with Winesap, the scion variety slightly outgrowing the framework, except with Jonathan and Jubilee. Antonovka was used as a framework on seedlings of Canada Baldwin, Duchess and McIntosh and on the clonal rootstocks Malling II and Malling XVI. In some instances Antonovka appeared to have exerted a slightly dwarfing influence on the resulting trees. Resistant to crown rot. Worthy of further trial.

Atlas: (Central Experimental Farm, Ottawa, seedling of Winter St. Lawrence): (C). Hardy; crotches moderately wide-angled but branches tended to upright and compact growth; made fairly smooth unions with Delicious, the framework slightly outgrowing the scion. Atlas was used as a framework on seedlings of Canada Baldwin and McIntosh; it did not appear to have exerted a dwarfing influence on the resulting trees. Not tested for crown rot. Of doubtful value.

Beauty Crab: (South Dakota, seedling of Cherry Crab): (D). Hardy; crotches rather narrow-angled; made very uneven unions with Delicious but fairly smooth unions with Spartan, both varieties outgrowing the framework. Beauty was used as a framework on seedlings of Canada Baldwin and French Crab and on the clonal rootstock Malling XVI: it appeared to have exerted some dwarfing influence on the resulting trees. Susceptible to crown rot. Not recommended.

Bedford Crab: (Dominion Experimental Farm, Brandon, seedling of Cluster): (C). Hardy; crotches rather narrow-angled; made only fairly smooth unions with Jubilee, the scion outgrowing the framework. Bedford was used as a framework on seedlings of McIntosh: it appeared to have exerted a slightly dwarfing influence on the resulting trees. Moderately susceptible to crown rot. Not rëcommended.

Canadà Baldwin: (Quebec): (A). Hardy; crotches rather narrow-angled but the framework was strong and not susuceptible to breakage: made rery smooth unions with Delicious, Jubilee, McIntosh, Newtown, Stayman and Winesap, but with Jonathan there was a slight tendency for the framework to 
outgrow the scion. Canada Baldwin was used as a framework on seedlings of Canada Baldwin, French Crab and McIntosh and on the clonal rootstocks Malling II and Malling XVI: it did not appear to have exerted a dwarfing influence on the resulting trees. Susceptible to crown rot. Recommended.

Charlamoff: (Russia): (B). Hardy; crotches moderately wide-angled and strong but branches rather upright and compact; made very good unions with Jonathan, but with Delicious, Jubilee, Newtown, Stayman and Winesap there was a slight tendency for the scion to outgrow the framework, this tendency being more noticeable with Newtown than with other varieties. Charlamoff was used as a framework on seedlings of Canada Baldwin, Duchess and McIntosh and on the clonal rootstocks Malling II and Malling XVI: it appeared to have exerted a slightly dwarfing influence on the resulting trees. Moderately susceptible to crown rot. Worthy of further trial.

Columbia Crab: (Central Experimental Farm, Ottawa, Malus baccata $\times$ Broad Green): (C). Hardy; crotches wide-angled and branches rather upright and compact; made good unions with Delicious, though with a slight tendency for the scion to outgrow the framework. Columbia was used as a framework on seedlings of Canada Baldwin and Columbia and on the clonal rootstocks Malling II and Malling XVI: it appeared to have exerted a slightly dwarfing influence on the resulting trees. Slightly susceptible to crown rot. Worthy of further trial.

Dolgo Crab: (Russia): (C). Hardy; crotches very narrow-angled; made good unions with Jubilee, there being a slight tendency for the scion to outgrow the framework. Dolgo was used as a framework on seedlings of McIntosh. In some instances Dolgo appeared to have exerted a slightly dwarfing influence on the resulting trees. Resistant to crown rot. Not recommended.

Florence Crab: (Peter M. Gideon, Excelsior, Minnesota): (D). Hardy; crotches rather narrow-angled; made only a fair union with Spartan, the scion outgrowing the framework. Florence was used as a framework on seedlings of McIntosh: it appeared to have exerted a slightly dwarfing influence on the resulting trees. Slightly susceptible to crown rot. Not recommended.

Haas: (Missouri): (C). Hardy; crotches rather narrow-angled; branches long and slender; made very good unions with Delicious, but only fairly good unions with Stayman, with a slight tendency for the scion to outgrow the framework. Haas was used as a framework on seedlings of McIntosh and on the clonal rootstock Malling XVI: it did not appear to have exerted a dwarfing influence on the resulting trees. Resistant to crown rot. Of doubtful value.

Haralson: (University of Minnesota Fruit Breeding Farm, Excelsior, Minnesota): (C). Hardy; crotches moderately wide-angled; made fairly good unions with Delicious, Jubilee and Stayman, all these scions having a tendency to outgrow the framework. Haralson was used as a framework on seedlings of Canada Baldwin. French Crab, and McIntosh and on the clonal rootstocks Malling II and Malling XVI; it appeared to have exerted a slightly dwarfing influence on the resulting trees. Resistant to crown rot. Of doubtful value.

Hibernal: (Russia): (A), Hardy; crotches usually wide-angled and with the appearance of being mechanically strong. However, under heavy crops of fruit in the early years of bearing, the crotches showed an unexpected tendency to pull out of their sockets and split. There was also a tendency for the more horizontal branches to droop, twist sideways and crack longitudinally along the grain of the wood. Hibernal made very good unions with Delicious, Newtown, Spartan, Stayman and Winesap, though with a slight tendency for the scion to outgrow the framework. With Jonathan there was a tendency for the framework to outgrow the scion. Hibernal was used as a framework on seed- 
lings of Anis, Antonovka, Canada Baldwin, Duchess, French Crab, McIntosh, Malus baccata, Wealthy and Yellow Transparent and on the clonal rootstocks Malling II and Malling XVI. In some instances, Hibernal appeared to have exerted a slightly dwarfing influence on the resulting trees. Moderately susceptible to crown rot. Not recommended.

Hyslop Crab: (origin unknown): (C). Hardy; crotches somewhat narrowangled, made fairly good unions with Delicious, though with a slight tendency for the scion to outgrow the framework; it also made satisfactory unions with Spartan. Hyslop was used as a framework stock on seedlings of McIntosh: it did not appear to have exerted a dwarfing influence on the resulting trees. Susceptible to crown rot. Not recommended.

Lobo: (Central Experimental Farm, Ottawa, seedling of McIntosh): (C). Hardy; crotches moderately wide-angled; made good unions with Delicious, though with a slight tendency for the scion to outgrow the framework. Lobo was used as a framework on seedlings of Canada Baldwin and French Crab and on the clonal rootstocks Malling II and Malling XVI: it did not appear to have exerted a dwarfing influence on the resulting trees. Not tested for crown rot. Worthy of further trial.

Malus baccata: (Siberia): (B). Hardy; crotches moderately wide-angled; under heavy cropping in the early years of bearing, there was a tendency for the crotches to pull out of their sockets and to split; made only fair unions with Delicious and Spartan, the scion outgrowing the framework; also made only fair unions with Jubilee, there being a tendency for the framework to outgrow the scion. Malus baccata was used as a framework on seedlings of Canada Baldwin, French Crab and McIntosh and on the clonal rootstocks Malling II and Malling XVI: it did not appear to have exerted a dwarfing influence on the resulting trees. Susceptible to crown rot. Not recommended.

Malus robusta No. 5: (originated at the Central Experimental Farm, Ottawa, as a clonal rootstock): (D). This stock was added to the experiment at a later date than the others and could not be fully evaluated. Preliminary tests indicated that the trees were very vigorous but slightly susceptible to crown rot. Worthy of trial.

McIntosh: (Ontario, chance seedling): (A). Moderately hardy; crotches moderately wide-angled; made good unions with Delicious, Jonathan, Newtown, Stayman and Winesap. There was a slight tendency for the scion to outgrow the framework, except with Jonathan which showed the opposite trend. McIntosh was used as a framework on seedlings of MeIntosh and on the clonal rootstocks Malling II and Malling XVI: it did not appear to have exerted a dwarfing influence on the resulting trees. Slightly susceptible to crown rot and anthracnose. Recommended for more favored districts only.

Melba: (Central Experimental Farm, Ottawa, seedling of McIntosh): (C). Moderately hardy; crotches rather narrow-angled; made fairly good unions with Delicious and Newtown though with a slight tendency for the scion to outgrow the framework. With Stayman and Winesap, Melba marle only fair unions, the scion outgrowing the framework, while with Jonathan the union was good, there being a slight tendency for the framework to outgrow the scion. Melba was used as a framework on seedlings of MeIntosh and on the clonal rootstock Malling XVI. In some instances, Melba appeared to have exerted a slightly dwarfing influence on the resulting trees. Resistant to crown rot but susceptible to anthracnose and sunscald. Not recommended.

Olga Crab: (Agricultural Experiment Station, Brookings, South Dakota, Duchess of Oldenburg $X$ Cherry Crab): (C). Hardy; crotches variable, rather narrow-angled; made only fair unions with Delicious and above fair unions 
with Jubilee, both scions outgrowing the framework. Olga was used as a framework on seedlings of Canada Baldwin and McIntosh and on the clonal l'ootstocks Malling II and Malling XVI; it appeared to have exerted a very slightly dwarfing influence on the resulting trees. Susceptible to crown rot and to crotch splitting. Not recommended.

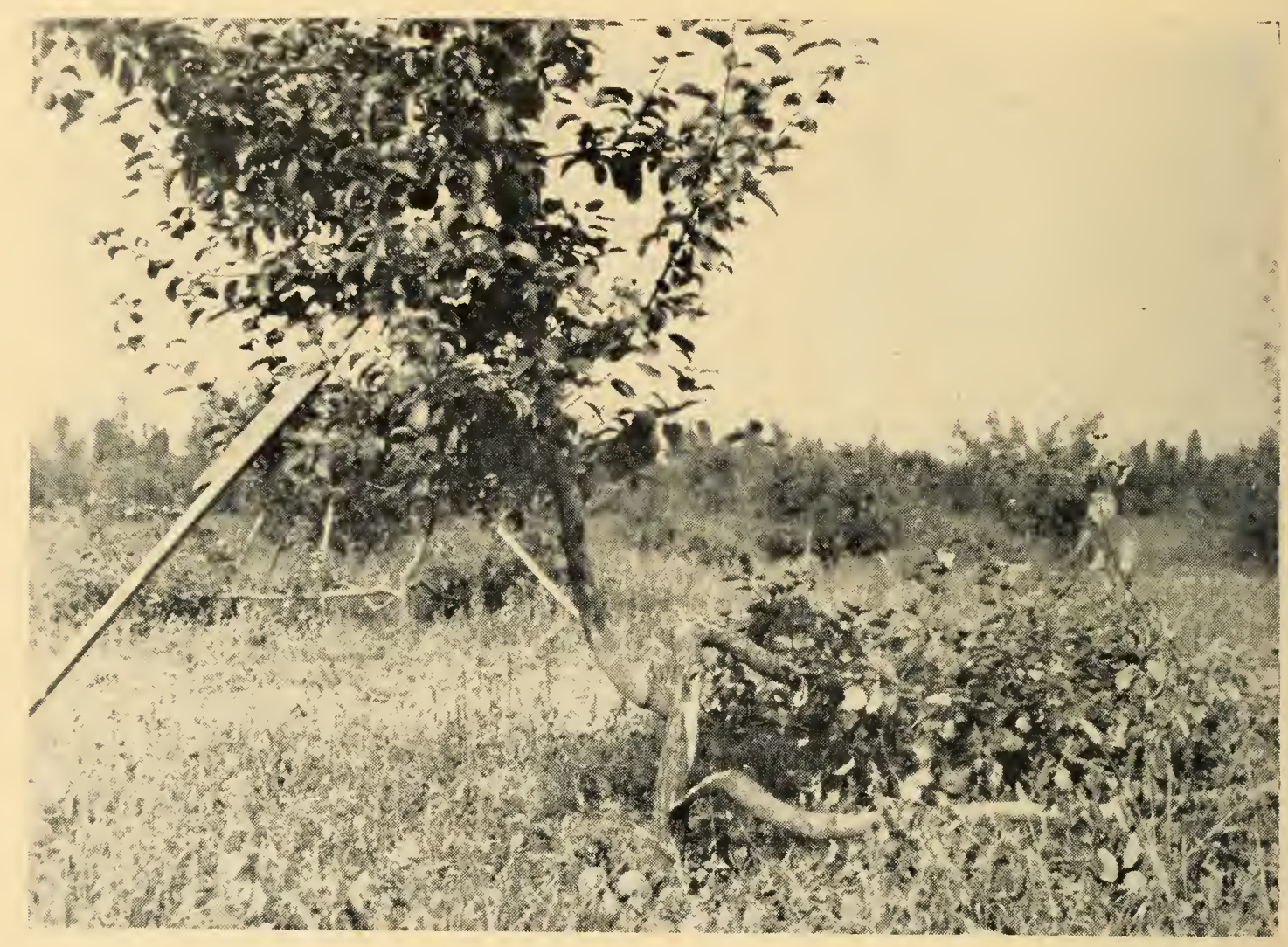

Figure 7.-An example of crotch splitting in Robin Crab, an undesirable framework stock. Breakage of this type occurred in several crabapple stocks and also in Hibernal. Kelowna, B.C., September, 1950.

Osman Crab: (Central Experimental Farm, Ottawa, Siberian Crab $\times$ Osimoe): (B). Hardy; crotches moderately wide-angled; made only fair unions with Delicious, Jonathan, Newtown, Stayman and Winesap, the scion outgrowing the framework, and with Jubilee, the framework outgrowing the scion. With Spartan the union was better, the framework only slightly outgrowing the scion. Osman was used as a framework on seedlings of Canada Baldwin and McIntosh and on the clonal rootstocks Malling II and Malling XVI. In some instances, Osman appeared to have exerted a slightly dwarfing influence on the resulting trees. Moderately susceptible to crown rot. Of doubtful value.

Pioneer Crab: (Central Experimental Farm, Ottawa, Malus baccata $X$ Tetofsky): (D). Hardy; crotches narrow-angled; made fairly good unions with Delicious, though with a slight tendency for the scion to outgrow the framework. Pioneer was used as a framework on seedlings of Canada Baldwin: it exerted.a dwarfing influence on the resulting trees. Not tested for crown rot. Not recommended.

Robin Crab: (Central Experimental Farm, Ottawa, Malus baccata $\times$ Simbrisk No. 9): (C). Hardy; crotches rather narrow- to moderately wide-angled, and susceptible to splitting (Fig. 7) ; made only fair unions with Delicious and Jubilee, both soions outgrowing the framework. Robin was used as a framework on seedlings of Canada Baldwin and McIntosh: it exerted a dwarfing influence on the resulting trees. Resistant to crown rot. Not recommended. 
Sheriff: (Pennsylvania): (D). Hardy; crotches rather narrow-angled; made fair unions with Delicious, though with a tendency for the scion to outgrow the framework. Sheriff was used as a framework on seedlings of French Crab; it did not appear to have exerted a dwarfing influence on the resulting trees. Not tested for crown rot. Of doubtful value.

Tony Crab: (Central Experimental Farm, Ottawa. Malus baccata $\times$ McMahon White): (B). Hardy; crotches moderately wide-angled and with a tendency to split; made fairly good unions with Jubilee and Spartan but only fair unions with Delicious, there being a tendency for all three scions to outgrow the framework. Tony was used as a framework on seedlings of Canada Baldwin, French Crab, Martha and McIntosh and on the clonal rootstock Malling XVI. In some instances Tony appeared to have exerted a slightly dwarfing influence on the resulting trees. Moderately susceptible to crown rot. Not recommended.

Transcendent Crab: (Origin unknown): (C). Hardy; crotches moderately wide-angled and strong; made good unions with Delicious, though with a tendency for the scion to slightly outgrow the framework. Transcendent was used as a framework on seedlings of Canada Baldwin, and on the clonal rootstock Malling II: it did not appear to have exerted a dwarfing influence on the resulting trees. Slightly susceptible to crown rot. Worthy of further trial.

Virginia Crab: (Iowa): (A). Hardy; crotches wide-angled and strong. Union compatibility was variable and there was a tendency for the framework to make poor unions with the scion. With Delicious, Jubilee, Newtown, Spartan, Stayman and Winesap there was a tendency for a rather large bulge at the point of union. Breakage of branches did not result from these enlarged unions even when carrying heavy loads of fruit. With Jonathan, unions were comparatively smooth, though with a tendency for the framework to outgrow the scion. Virginia, notwithstanding its outstanding vigor, when double-worked to the scion variety had a tendency to develop trees of dwarfing, low spreading and open centre habit on seedlings of Canada Baldwin, Columbia, Duchess, French Crab and McIntosh and on the clonal rootstocks Malling II and Malling XVI. On seedlings of Anis and Malus baccata, there was some indication that Virginia tended to develop trees of more compact habit and with smoother unions with Delicious. In general, the behaviour of this stock was very variable and unreliable. Slightly susceptible to crown rot. Not recommended.

Winter St. Lawrence: (England): (B). Moderately hardy; crotches moderately wide-angled; made good unions with Delicious, Jubilee, Newtown, Stayman and Winesap. With Winesap there was a slight tendency for the scion to outgrow the framework, whereas with Jubilee there was a slight tendency for the framework to outgrow the scion. Jonathan unions were only fair, the framework outgrowing the scion. Winter St. Lawrence was used as a framework on seedlings of McIntosh and on the clonal rootstock Malling XVI: it did not appear to have exerted a dwarfing influence on the resulting trees. Susceptible to crown rot and to sunscald. Of doubtful value.

Wolf River: (Wisconsin): (C). Hardy; crotches moderately wide-angled; made good unions with Delicious and Jubilee. Wolf River was used as a framework on seedlings of McIntosh: it did not appear to have exerted a dwarfing influence on the resulting trees. Susceptible to crown rot. Of doubtful ralue.

\section{DISCUSSION}

The experiments reported here have not yet provided sufficient eridence to evaluate fully the different framework stocks undergoing trial. The tests should be continued, probably 20 to 25 years from planting, in order to arrive at ralid conclusions which may provide a reasonably safe guide as to the desirability of 
the more promising stocks when used in developing commercial orchards throughout the colder tree-fruit areas of British Columbia. Nevertheless it is possible to make the following statements regarding the comparative merits of Canada Baldwin, McIntosh, Hibernal and Virginia Crab, which have been tested extensively as frameworks for Delicious.

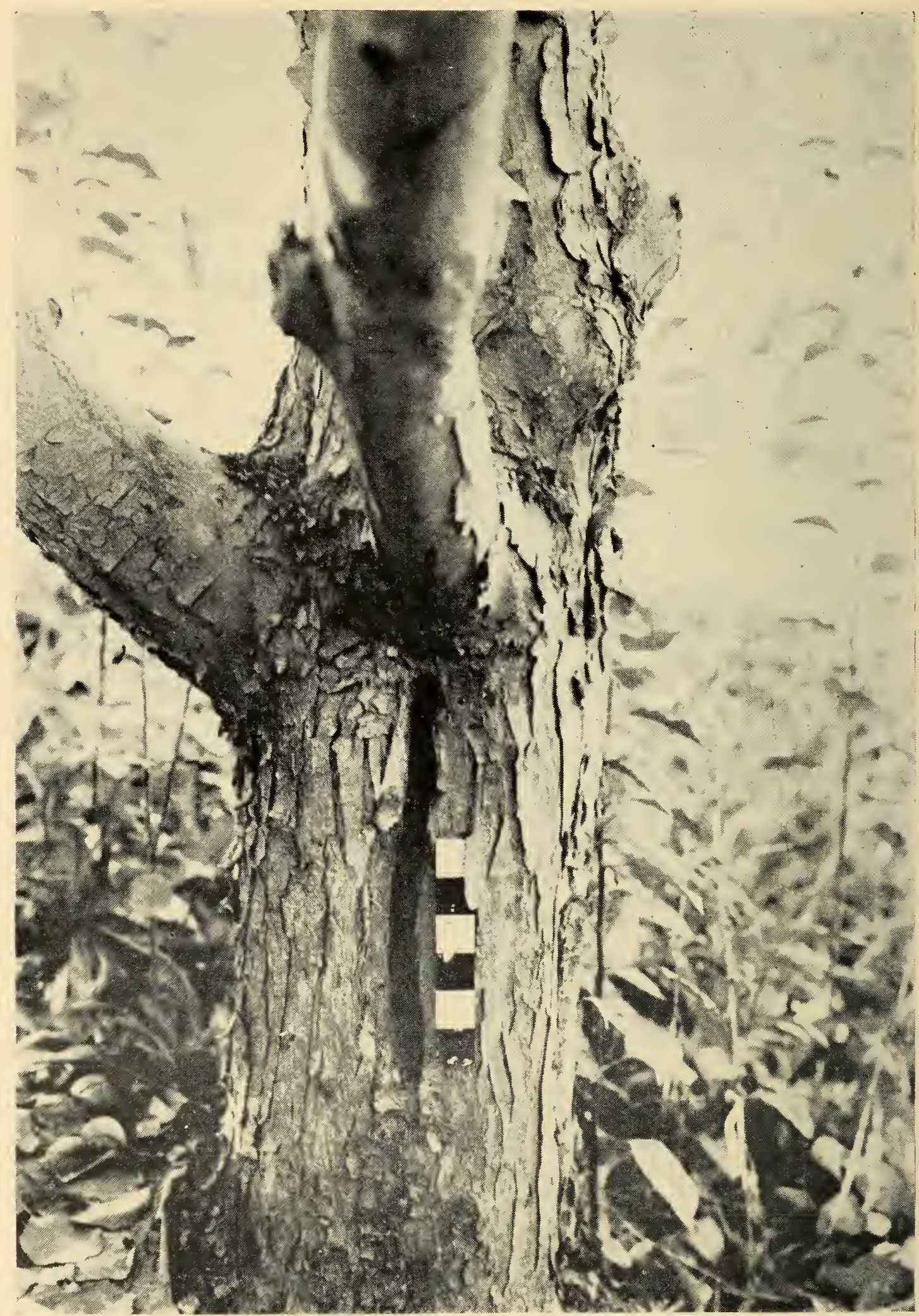

Figure 8.-In cold areas McIntosh is subject to winter injury. Eighteen-year-old McIntosh tree showing effect of winter injury on the trunk during the winter of 1935-36. Vernon, B.C., 1938. 
Canada Baldwin: This framework has been used extensively in British Columbia for over 25 years. It is almost as hardy as Hibernal and makes an excellent framework which unites well with Delicious, resulting in large, strong trees capable of carrying heavy crops without breakage.

The weakness of Canada Baldwin as a framework lies in the fact that it is susceptible to crown rot. This has suggested the advisability of budding Canada Baldwin high enough to permit planting the resulting trees with the bud-union at least six inches above ground level. Only hardy, crown-rot-resistant rootstocks should be used.

McIntosh: This variety makes well-balanced frameworks which have united well with Delicious, resulting in vigorous trees which are productive and structurally strong. Furthermore, McIntosh is resistant to crown rot. The weakness of this variety as a framework for Delicious lies in the fact that it is itself subject to trunk and crotch injury where temperatures lower than $-30^{\circ} \mathrm{F}$. are experienced (Fig. 8). In districts with less extreme temperatures, McIntosh merits favorable consideration as a framework for Delicious.

Hibernal: This framework is hardier than McIntosh. This fact was demonstrated during the winter of $1949-50$, when Hibernal withstood $-40^{\circ} \mathrm{F}$. with only a trace of injury, whereas McIntosh trees were severely damaged. Hibernal has been used extensively as a framework stock in Eastern Canada and in Iowa. Acting on favorable reports from these areas, several thousand trees of Hibernal were propagated and distributed to growers in British Columbia for trial. These trees grew well. When budded to Delicious they made smooth unions and produced vigorous, productive trees. In most instances Hibernal formed crotches with a wide angle and with the appearance of great structural strength. Unfortunately, however, in the early years of heavy bearing, many frameworks in widely separated areas have shown an unexpected tendency to split. In other instances, branches have pulled out of their sockets under the weight of heavy crops. There has also been a tendency for the more horizontal limbs to droop, twist sideways and crack longitudinally along the grain of the wood.

In using Hibernal as a framework, buds or grafts of the commercial variety have usually been placed 18 to 24 inches from the trunk in order to take advantage, not only of the hardy trunk and crotches, but also of the hardy main limbs. This method of top-working has probably aggravated the structural weaknesses of Hibernal, but there is evidence that, even when worked less than 12 inches from the trunk, Hibernal frameworks are not always strong enough to support heavy crops of Delicious. Hibernal is moderately susceptible to crown rot.

For these reasons Hibernal is no longer recommended for planting as a framework stock in British Columbia. In existing Hibernal orchards, special attention should be given to bracing the frameworks and propping hearily loaded limbs.

Virginia Crab: This framework has been used extensively in Towa. However, experience indicates that it is not suitable as a framerrork for Delicious under British Columbia conditions. Some good Delicious trees have been developed on Virginia, but in most orchards the results of using this stock have been very disappointing. Difficulty has been experienced in dereloping wellbalanced frameworks. The scaffold branches tend to leave the trunk at too flat an angle. There is a tendency for the framework to make poor unions with the scion variety. Furthermore, although Virginia shows great vigor in the early years, it has a tendency later to exert a dwarfing influence on the resulting trees. 


\section{ACKNOWLEDGMENTS}

The authors wish to acknowledge the helpful assistance of the late R. C. Palmer, Superintendent of the Dominion Experimental Station, Summerland, B.C., in the original organization of this project and in the review of the manuscript. The assistance of the growers in the various districts, in providing land and cultural care for the double-worked trees on trial in their orchards, is acknowledged with appreciation. Thanks are also extended to the District Horticulturists for their help in locating orchards and for their assistance to growers in the care of the trees. The authors also wish to acknowledge the co-operation of the Laboratory of Plant Pathology, Summerland, in the conduct of the crown rot inoculation tests. The photographs used in this bulletin are the work of J. E. Britton.

\section{REFERENCES}

1. Alderman, W. H. Hardy Stocks. American Fruit Grower, May, 1937.

2. Blair. D. S. Present status of the apple rootstock and double-working trials in Eastern Canada, Sci. Agr. 20: 150-154. 1939.

3. Blair, D. S. Report of Committee on Horticultural Research, Ottawa, 1942.

4. Daris, M. B.. D. S. Blair and H. B. Cannon. Winter injury. Div. Hort, Exp. Farms Service, Progress Rpt. 5-14, 1934-1948.

5. Filewicz, W., and I. Modlibowska. The influence of a scion variety on the resistance of the roots against frost. Proc. Amer. Soc. Hort. Sci. 38:348-352. 1941.

6. Hewetson, F. N. Growth and yield of Steele Red apple trees as influenced by the use of various double-worked interstocks. Proc. Amer. Soc. Hort. Sci. 40:264-268. 1942.

7. Hilborn, M. T. and J. H. Waring. A summary of investigations on the use of hardy trunk-forming stocks in Maine. Proc. Amer. Soc. Hort. Sci. 48:151-164. 1946.

8. Hilkenbaeumer, F. Das Verhalten von Apfel-Stammbildnern in der Baumshule. KuehnArchiv $62: 65-75.1949$.

9. Maney, T. J. Stock and scion relationship with reference to double-worked stocks. Proc. Amer. Soc. Hort. Sci. 35:390-392. 1937.

10. Maney, T.J. and H. J. Plagge. Three apple stocks especially well adapted to the practice of double-working. Proc. Amer. Soc. Hort. Sci. 32:330-333. 1934.

11. Maurer, K. J. Vorlaeufiger Bericht ueber einem Stamm- bzw. Geruestbildnerversuch. Zuechter 20:346-352. 1950 .

12. McClintock, J. A. Preliminary observations of the fruiting of varieties other than Grimes on Virginia Crab stocks. Proc. Amer. Soc. Hort. Sci. 40:275-276. 1942.

13. McClintock, J. A. A strain of McIntosh compatible with Virginia Crab stocks. Proc. Amer. Soc. Hort. Sci. 49:181-182. 1947.

14. Overley, F. L. Observations on the Hibernal hardy rootstock in Iowa. Proc. Wash. State Hort. Assn. $47: 173-174.1951$.

15. Talbert, T. J. Budding and grafting standard apple varieties on hardy stocks. Univ. Missouri Agr. Exp. Stat. Bull. 525. 1945.

16. Tukey, H. B. and-K. D. Brase. An uncongeniality of the McIntosh apple when topworked on to Virginia Crab. Proc. Amer. Soc. Hort. Sci. 43:139-142. 1943. 


\section{PART II-ROOTSTOCKS}

\section{INTRODUCTION}

Commercial apple trees are usually propagated by budding or grafting. This procedure is necessary because apple varieties do not come true from seed, nor can they be raised easily from cuttings or layers.

In British Columbia the use of apple seedling rootstocks over the past 50 years has resulted in orehards having a fairly high degree of uniformity, commensurate with conditions of culture, soil and moisture. There has been, however, some variation between seedling rootstocks in their susceptibility to crown rot.

Seedling rootstocks usually produce large trees, with consequent high cost of pruning, spraying, thinning and picking. The use of clonal*, rather than seedling, rootstocks offers one possible means of controlling the size and disease resistance of the trees.

The East Malling Research Station in Kent, England, has classified and named a series of clonal apple rootstocks, Malling I to Malling XVI, which can be used to produce trees of various sizes, from the dwarf Malling IX to the very large Malling XII. In recent years other clonal apple stocks, some of them resistant to woolly aphid, have been added to the East Malling list.

\section{REVIEW OF LITERATURE}

There is a great deal of experimental evidence to indicate that the size and productivity of apple trees can be influenced to some extent by the use of clonal rootstocks. From the voluminous literature on this subject, the following references have been selected.

Hoblyn (5) presents figures which show differences as great as three to five times, in size of tree and in amount of crop, between mature trees of the same variety on two different clonal rootstocks.

The advantages of clonal rootstocks with known performance are generally recognized, and these rootstocks are widely used in Western Europe. On the American continent, however, they are accepted with reserve because these rootstocks are more expensive and more difficult to propagate than seedling stocks, (Mann and Keane, 7; Tukey, 13). Also, the Malling clonal rootstocks, which are those most widely used, are reported to be winter tender. (Hilborn, and Waring, 4; Davis, Blair and Cannon, 3). Further, certain Malling stocks show poor anchorage. (Shaw, 9; Brase, 2 ; Hoblyn, 5). It has also been demonstrated that in North America trees on seedling rootstocks show only slightly greater variability than those on clonal rootstocks, (Yerkes and Sudds, 15; Tukey, 13). In fact, Upshall (14) has found that, in Ontario, trees on some Malling rootstocks may even be more variable than when grown on French Crab seedlings.

There is, however, in the United States and Canada some demand for trees of smaller than standard size and of early bearing characteristics, and good results have been obtained with Malling I, II, VII and XIII rootstocks, (Sudds, 12; Shaw, 10; Tukey, 13). Good performance has been shown also by Malling XVI rootstock, which produces trees of standard size, (Brase, 2), or slightly smaller than standard, (Tukey, 13).

* The term "clonal" rootstock as used in this Bulletin means one which has been regetatively raised by means of stooling or layering, or by growing it from a cutting. in contrast to a seedling rootstock which has been raised from seed. 

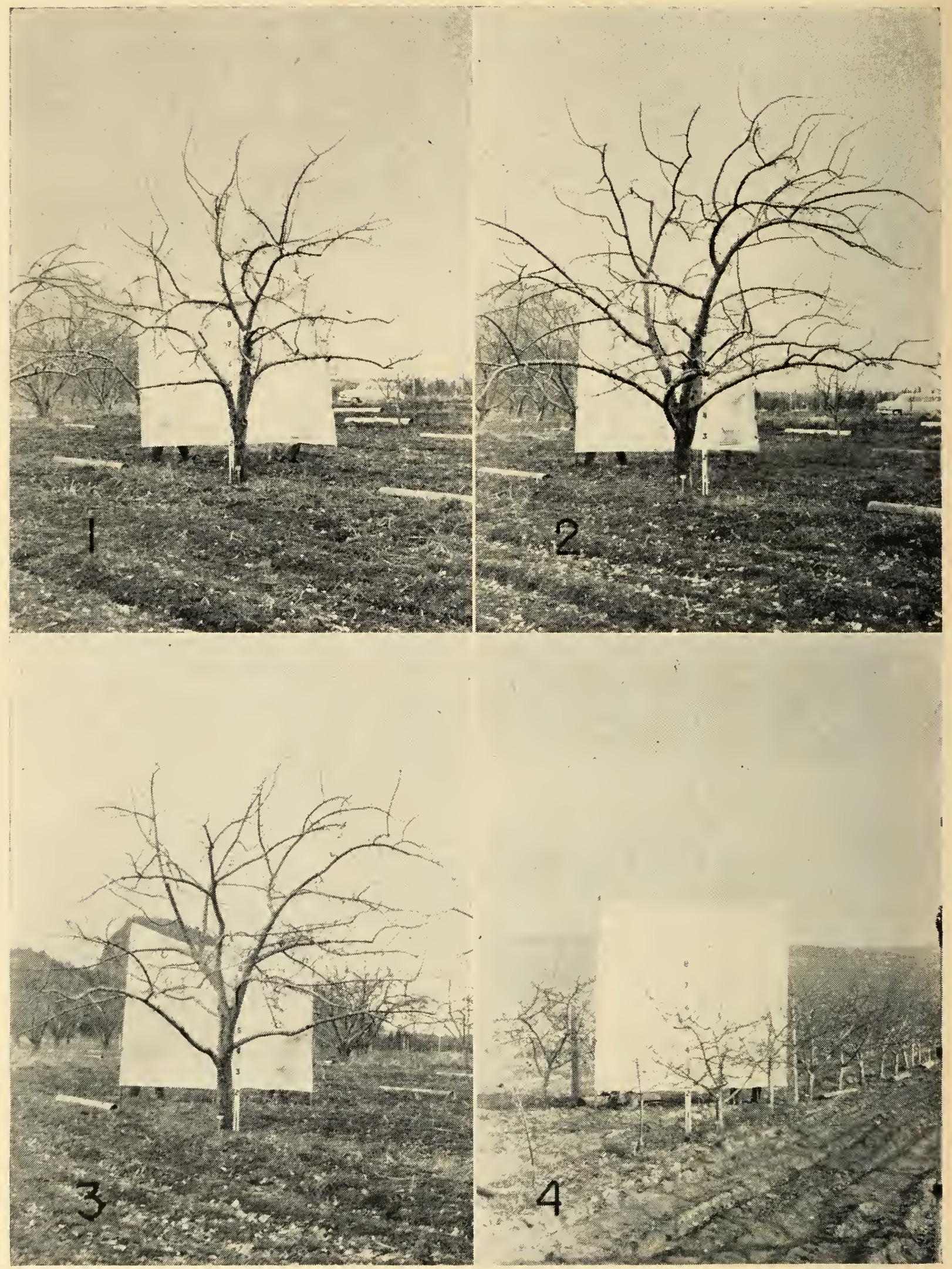

Figure 9--Delicious on various rootstocks: (1) on Malling II at 20 years; (2) on Malling XVI at 20 years; (3) on Melba seedling at 20 years; (4) on Malling IX at 15 years. 


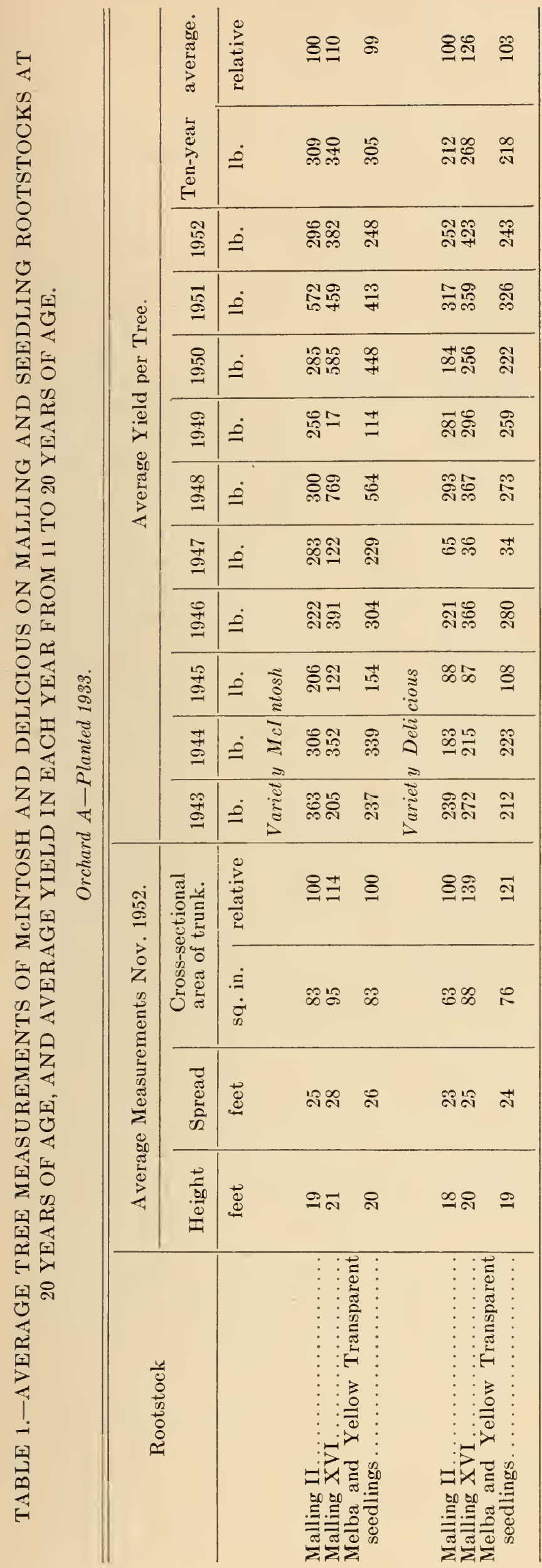

氜

동

20

존

9

4

W

0

E

0

号

舅

负

40

긍

势

妿

봉젓

出可

瓷吉

는

年

毕国

空

武

巫

过

돈

불

될근

된

这

곡

3

i

氠

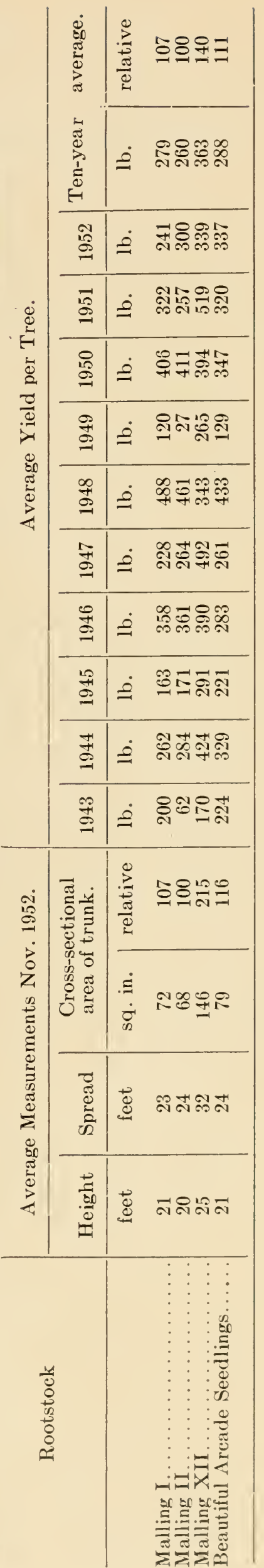




\section{ROOTSTOCK EXPERIMENTS IN BRITISH COLUMBIA}

\section{Earlier Plantings at the Station}

The success of clonal stocks in England encouraged this Station and other institutions in North America to introduce these stocks some 25 years ago. It was hoped that they would show superiority over the seedling rootstocks then in use and gradually replace them.

At the Summerland Experimental Station the first Malling stocks were imported in 1925. In 1933, 1934 and 1938 three orchards were planted to commercial varieties budded on certain of these stocks and on seedlings. These orchards were situated on fairly level bench land, the soil being a rather fertile sandy loam underlaid with open gravelly subsoil. The orchards were raised under irrigation and received the nutritional, pruning, spraying and thinning treatments which are customary in commercial orchards of this district.

Two of these orchards were removed after the 1952 season and it is now possible to evaluate some aspects of the performance of all three orchards. Tree measurements in 1952 are presented. The heights and spreads were measured in feet, and the cross-sectional area of the trunk in square inches, at about one foot above ground level, was recorded. Yields in pounds, including windfalls, ale shown for each of the ten years 1943 to 1952 . This period covers the years when the trees may be considered to have settled into production.

Orchard A. This planting was made in 1933 and consisted of five trees each of McIntosh and Delicious on Malling II and Malling XVI rootstocks and on seedlings of Melba and Yellow Transparent. The planting distance was $30^{\prime} \times 30^{\prime}$. In Table 1 measurements and yields of these trees are presented.

Table 1 shows that, at 20 years of age, MeIntosh and Delicious on Malling XVI were somewhat larger in height, spread and trunk than trees on Malling II or on seedling rootstocks, (Fig. 9). The trees on Malling XVI also yielded more heavily over a 10-year period. On each rootstock, McIntosh produced larger trees and heavier yields than Delicious.

Orchard B. This planting was made in 1934 and consisted of six trees each of McIntosh on Malling I, Malling II, Malling XII and seedlings of Beautiful Arcade, a hardy Russian variety. The planting distance of this orchard also was $30^{\prime} \times 30^{\prime}$. In Table 2 are presented measurements and yields on the same basis as in Table 1.

Table 2 shows that trees on Malling XII rootstock were much larger in height, in spread and in trunk than trees on Malling I, Malling II or on seedling rootstocks, (Fig. 10). The trees on Malling XII yielded more heavily over a 10-year period, although not proportionately to their larger size.

Orchard $C$. This planting was made in 1938. The trees consisted of a number of varieties on Malling IX rootstock, but for the purpose of this comparison only nine trees of McIntosh and twelve trees of Delicious are considered. The orchard was planted in rows $15^{\prime}$ apart, the trees being spaced $8^{\prime}$ in the rows. In Table 3 are presented measurements and yields on the same basis as in Tables 1 and 2 . 


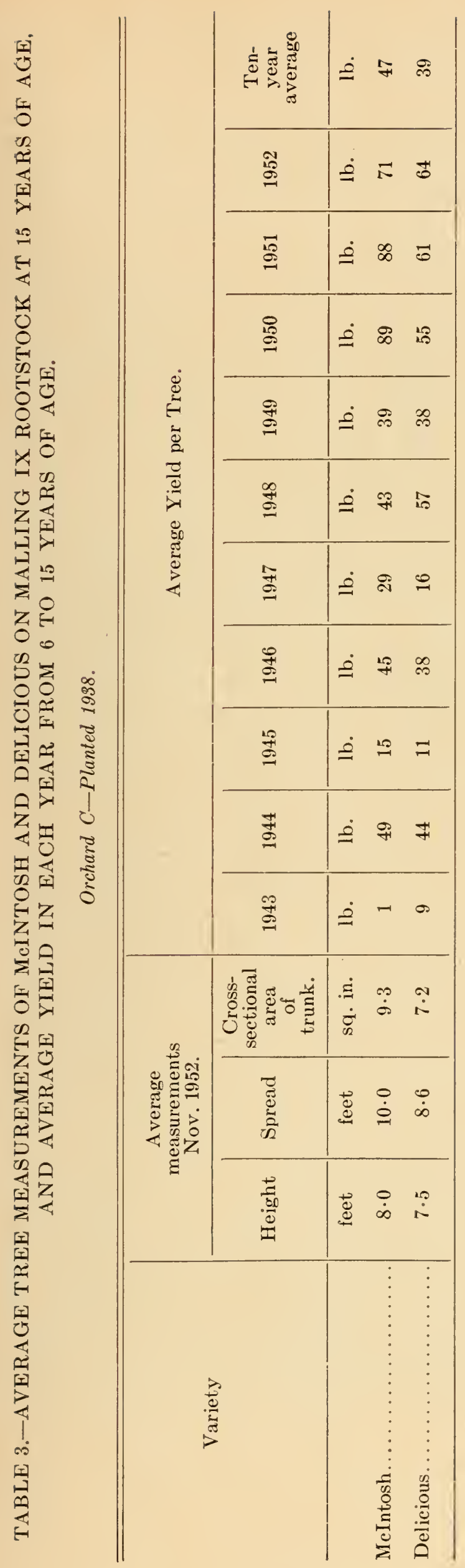


Table 3 shows that in Orchard C, on Malling IX rootstock, McIntosh produced larger trees and yielded more heavily than did Delicious. This relative performance of the two varieties was comparable with that of the trees in Orchard A on Malling II, on Malling XVI and on seedling rootstocks. It should, however, be noted that total yields, including windfalls, were recorded, the latter usually being heavier with McIntosh than with Delicious.

\section{Comparison of Yields: Orchards $A, B$ and $C$}

In comparing these three orchards it will be observed that there is one year's difference in age as between $\mathrm{A}$ and $\mathrm{B}$, and five years' difference as between $\mathrm{A}$ and $\mathrm{C}$. This latter difference is not so important as might appear, because the trees in Orchard C, on Malling IX rootstock, settled down into steady bearing at an earlier age than those on the other rootstocks.

In order to present some comparison between the performance of McIntosh trees on certain of the rootstocks under test, Table 4 has been prepared. In this table an average has been taken between the spreads and yields of the trees on Malling II in Orchards A and B. The trees on the three seedling rootstocks in these orchards have been similarly combined. Since there were no trees on Malling XII in Orchard A, and no trees on Malling XVI in Orchard B, the missing data have been calculated by the statistical procedure suggested by Snedecor (11, page 223), considering the orchards A and B as one experiment.

Using the tree spreads as a basis, an estimate has been made of the probable optimum spacing for each rootstock, and from this has been calculated the average yield per acre which might be expected from trees in their earlier years of settled production. 

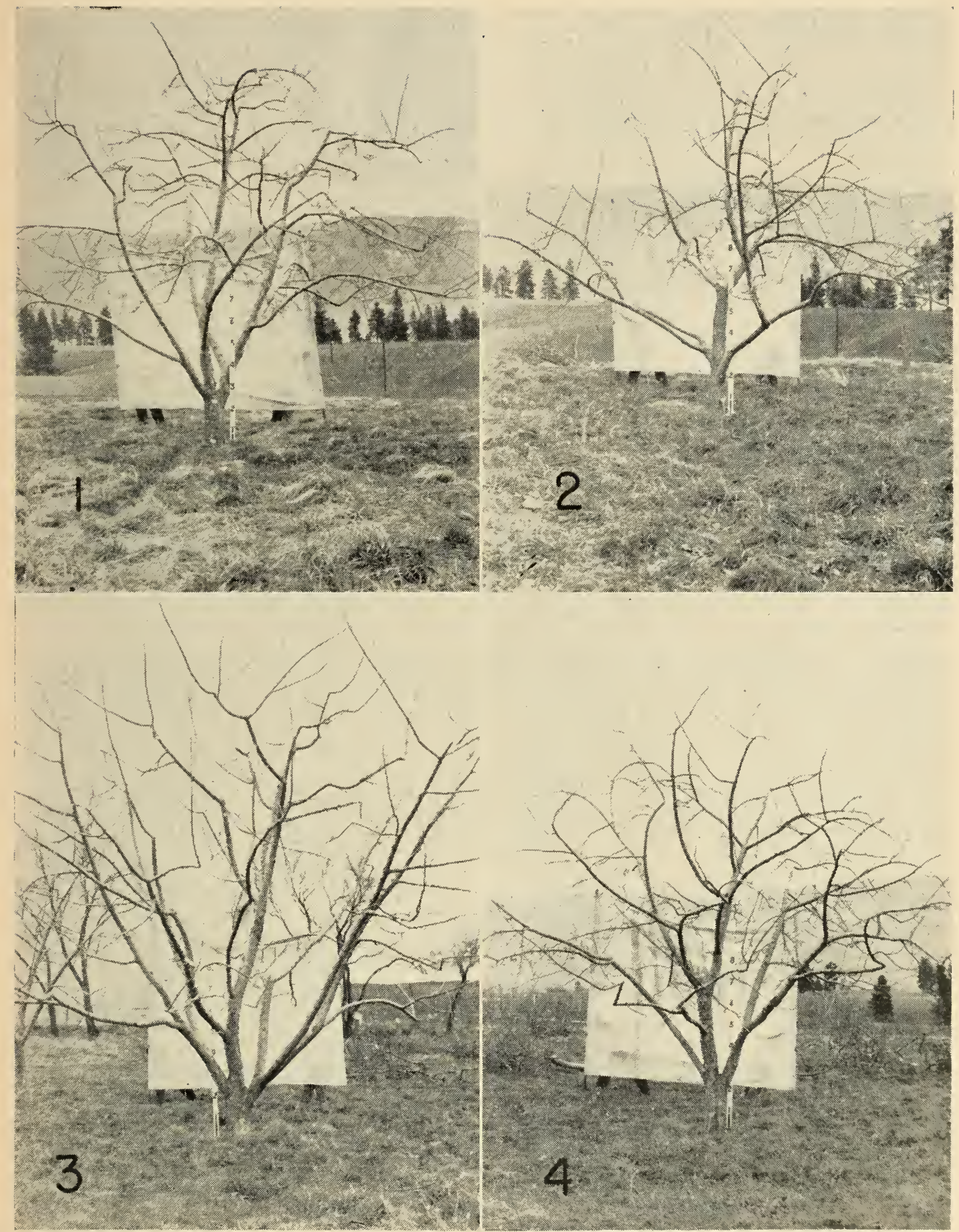

Figure 10-McIntosh on various rootstocks at 19 years: (1) on Malling I; (2) on Malling II; (3) on Malling XII; (4) on Beautiful Arcade seedling. 
TABLE 4.-AVERAGE ANNUAL YIELDS OF MCINTOSH TREES FOR TEN-YEAR PERIOD, 1943 TO 1952, CALCULATED ON AN ACREAGE BASIS.

\begin{tabular}{|c|c|c|c|c|c|c|}
\hline \multirow[t]{2}{*}{ Rootstock } & \multirow{2}{*}{$\begin{array}{c}\begin{array}{c}\text { Tree } \\
\text { spread } \\
\text { in } 1952\end{array} \\
\text { feet }\end{array}$} & \multirow{2}{*}{$\begin{array}{c}\begin{array}{c}\text { Proposed } \\
\text { planting } \\
\text { distances }\end{array} \\
\text { feet }\end{array}$} & \multirow[t]{2}{*}{$\begin{array}{l}\text { Number } \\
\text { of trees } \\
\text { per acre }\end{array}$} & \multirow{2}{*}{$\begin{array}{c}\begin{array}{c}\text { Actual yield } \\
\text { per tree } \\
\text { per year }\end{array} \\
\text { lb. }\end{array}$} & \multicolumn{2}{|c|}{$\begin{array}{l}\text { Theoretical } \\
\text { yield } \\
\text { per acre per year }\end{array}$} \\
\hline & & & & & lb. & $\begin{array}{l}\text { loose* } \\
\text { boxes. }\end{array}$ \\
\hline $\begin{array}{l}\text { Malling IX } \ldots \ldots \ldots \ldots \ldots \ldots \ldots \\
\text { Malling II } \ldots \ldots \ldots \ldots \ldots \ldots \ldots \\
\text { Malling XVI } \ldots \ldots \ldots \ldots \ldots \ldots\end{array}$ & $\begin{array}{l}10 \\
24 \\
27\end{array}$ & $\begin{array}{l}15 \times 8 \\
25 \times 25 \\
30 \times 30\end{array}$ & $\begin{array}{r}360 \\
70 \\
48\end{array}$ & $\begin{array}{r}47 \\
284 \\
323\end{array}$ & $\begin{array}{l}16,920 \\
19,880 \\
15,504\end{array}$ & $\begin{array}{l}564 \\
662 \\
517\end{array}$ \\
\hline 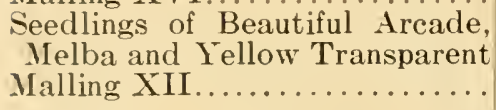 & $\begin{array}{l}25 \\
34\end{array}$ & $\begin{array}{l}30 \times 30 \\
35 \times 35\end{array}$ & $\begin{array}{l}48 \\
35\end{array}$ & $\begin{array}{l}296 \\
381\end{array}$ & $\begin{array}{l}14,208 \\
13,335\end{array}$ & $\begin{array}{l}474 \\
444\end{array}$ \\
\hline
\end{tabular}

* Loose apple boxes of 30 pounds net weight.

From Table 4 it will be noted that trees on Malling II have been the most productive when yields are calculated on an acreage basis, followed, in that order, by trees on Malling IX, on Malling XVI, on seedling rootstocks and on Malling XII. In making comparisons it should be observed that the seedlings used, Beautiful Arcade, Melba and Yellow Transparent, did not appear to produce trees as large as might be expected on such commonly used seedlings as Delicious and McIntosh. Malling I rootstock has not been included in Table 4. Its performance in other respects has been very similar to that of Malling II, but. Malling I stock has proved susceptible to crown rot and is not recommended.

These results are fairly consistent with those obtained by Kelsall (6), working in Nova Scotia with the same kinds of rootstocks.

\section{Color and Storage Characteristics of the Fruit}

Development of red color in McIntosh and Delicious was not noticeably affected by the type of rootstock used, except that the large McIntosh trees on Malling XII produced fruit with less red color than those on other stocks. In size and quality of fruit there appeared to be no consistent difference between one rootstock and another. Neither was there any wide difference in date of blossoming or in date of fruit maturity on the different rootstocks, although there was a tendency for the trees on Malling IX to blossom and mature their crop slightly earlier than on the other stocks.

With regard to storage characteristics, Nelson and Phillips (8) report that at the Central Experimental Farm, Ottawa, they found rather wide differences in the storage life of McIntosh apples grown on various Malling and seedling rootstocks. In general, their results indicated superior storage characteristics in fruit from Malling IX and from Anis seedlings, and inferior storage characteristics in fruit from Malling I and from Antonovka seedlings.

At the Summerland Experimental Station observational evidence, extending over 15 years work in common storage, in cold storage at $31^{\circ} \mathrm{F}$. and under ripening-room treatment at $65^{\circ} \mathrm{F}$, has not indicated any appreciable difference in the storage characteristics of McIntosh grown on Malling I, Malling II, Malling IX, Malling XII and Malling XVI, and on seedlings of Beautiful Arcade, Melba and Yellow Transparent.

\section{Later Plantings of Malling Stocks at the Station}

There are two other Malling clonal rootstocks in which British Columbia. growers are interested. These are Malling VII and Malling IV. English investigators have reported that Malling VII produces a tree intermediate in: 
size between Malling IX and Malling II (5), and that Malling VII has a rather poorly anchored root system (1). As regards size of tree, these findings are consistent with results obtained in the United States by Brase (2) and by Tukey (13). A grower in Penticton, British Columbia, has reported a planting of Winesap on Malling VII, now seven years old, which has been in production for several years; the trees have grown well and have not required staking.

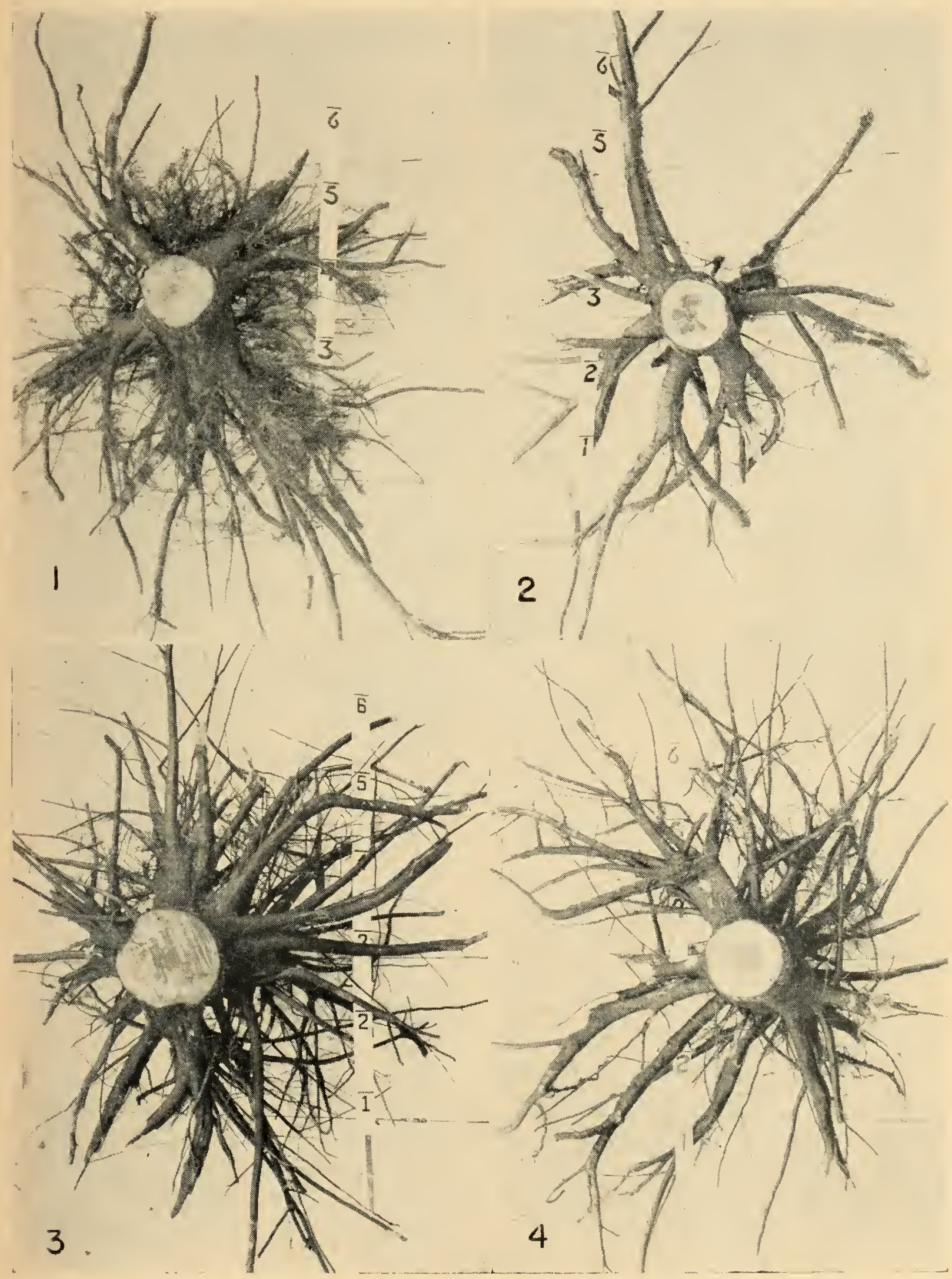

Figure 11.-Malling roots from McIntosh trees: (1) Malling I at 19 years; (2) Malling II at 19 years; (3) Malling XII at 19 years; (4) Malling XVI at 20 years. 
Hoblyn (5), working in England, reports that the rootstock Malling IV produces a tree slightly larger than Malling VII, that it is an early and heavy bearer, but that its root anchorage is poor.

Trial plantings of Malling VII and Malling IV have been made at the Summerland Experimental Station, the scion varieties used being Delicious, Golden Delicious, Jubilee, Lodi, McIntosh, Spartan and Wealthy. Experimental spacings of $12^{\prime} \times 20^{\prime}$ and $16^{\prime} \times 20^{\prime}$ are being tried. Half of the trees on Malling IV have been staked but so far no staking has been done with the Malling VII trees. The trees on Malling VII are now five years old and commenced to bear in their fourth year. The trees on Malling IV are two years old and have not yet fruited.

\section{Seedling Rootstocks at the Station}

Most of the seedlings which are in common commercial use, such as Delicious, McIntosh and Winesap, have proved in inoculation tests to be at least moderately susceptible to crown rot (see Table 5). Seedlings of Antonovka and of Columbia Crab have shown more resistance to this disease, and because of their hardy parentage they may be expected to be more cold resistant than seedlings of commercial varieties. Both have produced satisfactory trees of standard size, at least in their earlier years, but there is some indication that, whereas Antonovka seedlings appear to be fully compatible with all varieties which have been tried on them, seedlings of Columbia may not always be entirely compatible.

\section{Crown Rot Tests by Inoculation}

This experiment was started in 1936. The degree of susceptibility of a number of rootstocks, clonal and seedling, to crown rot (Phytophthora cactorum), was tested by inoculation of 1,497 trees which were grown by the Station for the purpose. The inoculation tests were conducted by the Laboratory of Plant Pathology, Summerland. The cumulative results are presented in Table 5 .

TABLE 5.-CROWN ROT RESISTANCE OF APPLE ROOTSTOCKS AS DETERMINED BY INOCULATION TESTS.

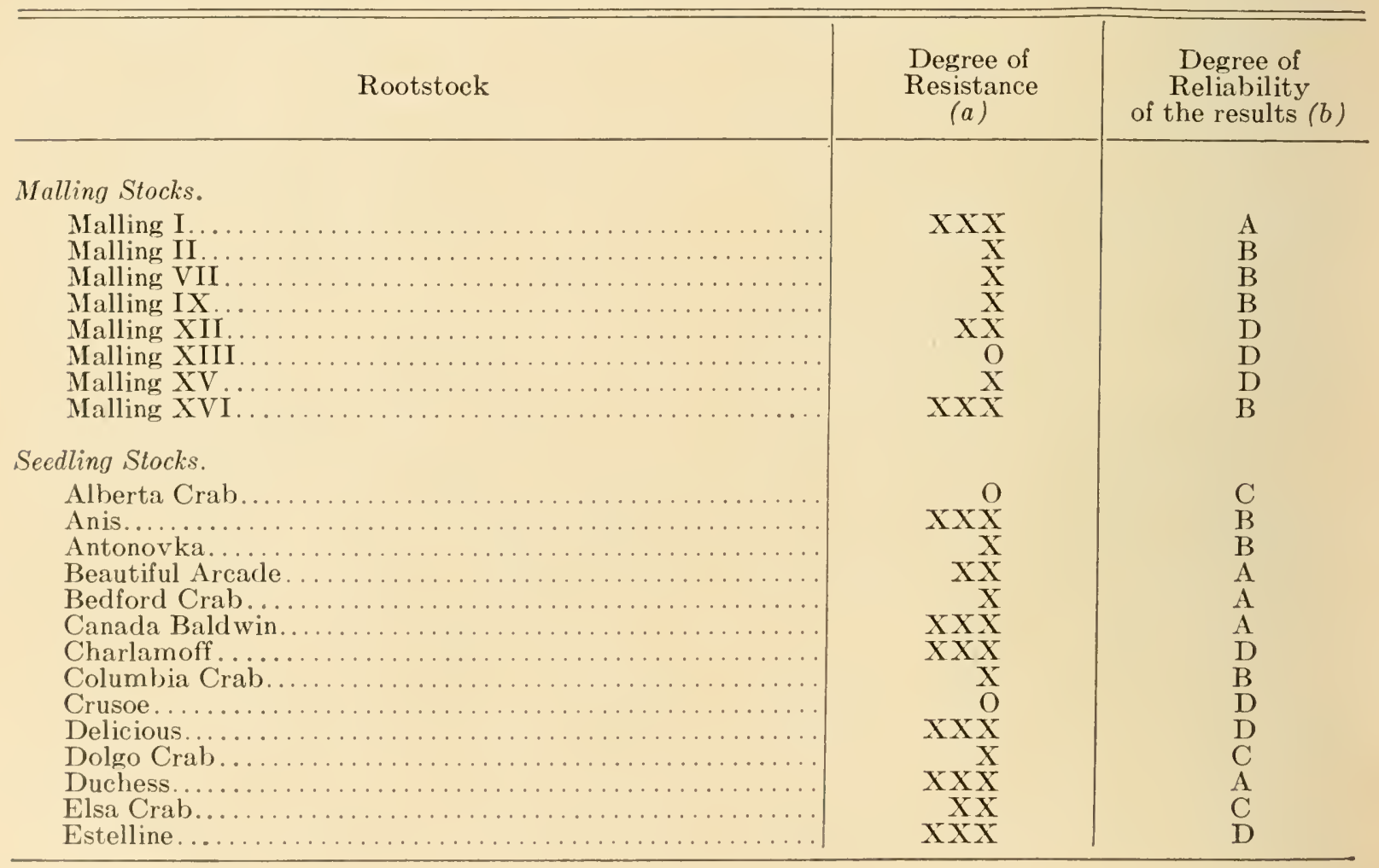




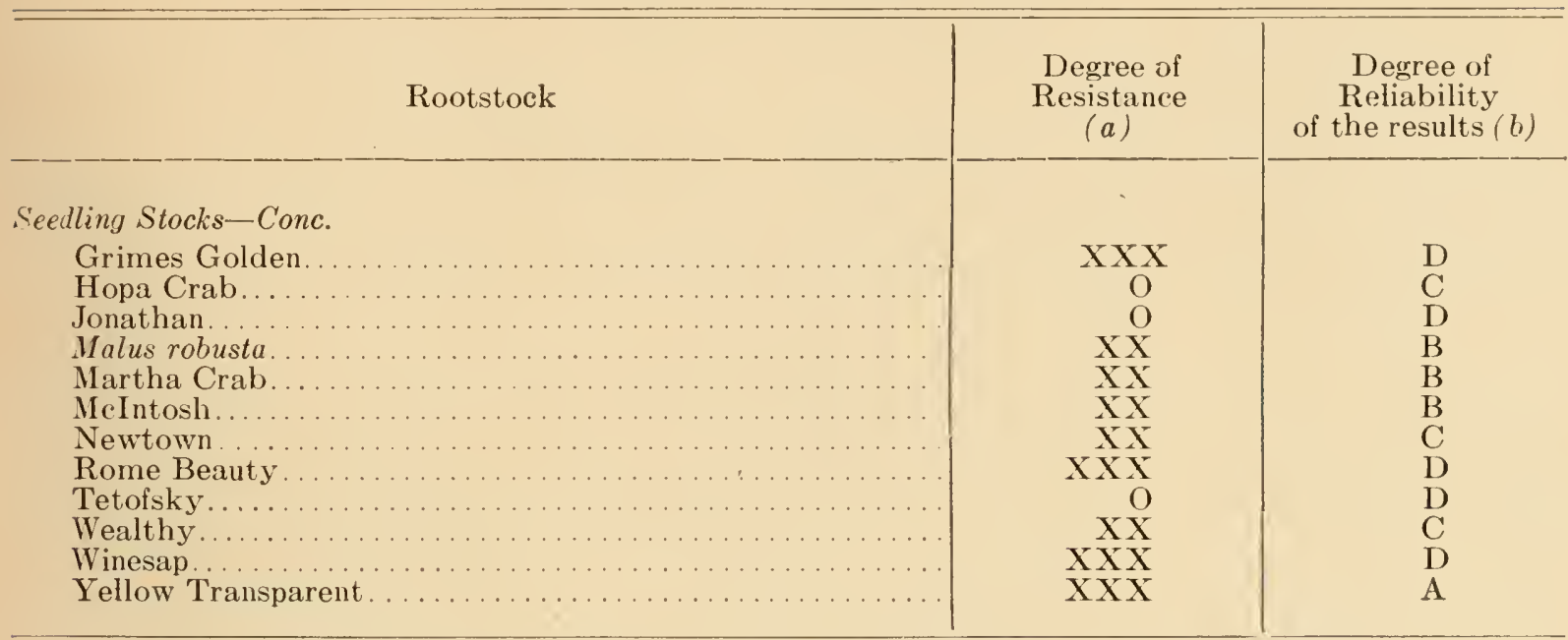

(a) Resistance O-Resistant-Less than 1 per cent of total possible infection.

$\mathrm{X}$-Slightly susceptible -1 per cent or more, but less than 10 per cent.

XX-Moderately susceptible-10 per cent or more, but less than 20 per cent. XXX-Susceptible 20 per cent or more.

(b) Reliability of Results.

The letters $\mathrm{A}, \mathrm{B}, \mathrm{C}$ and $\mathrm{D}$, in that order, indirate the degree of reliability of the results secured, A being the most reliable. Reliability is based on the number of trees used in the tests, on the number of yearly repetitions of the tests, and on the degree of uniformity of the findings.

\section{Growth Characteristics of Rootstocks}

In 1952 trees of orchards A and B were removed, using a bulldozer. Although some of the main roots and most of the small and fibre roots were broken off and remained in the ground, the removed portion of the root systems indicated fairly well the general growth characteristics of the various rootstocks. Each of the Malling stocks showed distinctive characteristics with respect to number and size of main roots and amount of fibre. The seedling roots were more variable in these respects. The root system of each individual tree was examined and described. The resulting data are summarized in Table 6. Typical roots of each of the clonal stocks were photographed and are shown in Fig. 11.

TABLE 6.-GROWTH CHARACTERISTICS OF ROOTSTOCKS.

\begin{tabular}{|c|c|c|c|c|}
\hline Rootstock & $\begin{array}{l}\text { Quantity of } \\
\text { main roots }\end{array}$ & $\begin{array}{c}\text { Size of } \\
\text { main roots }\end{array}$ & $\begin{array}{l}\text { Depth of } \\
\text { main roots }\end{array}$ & $\begin{array}{l}\text { Amount of } \\
\text { fibre roots }\end{array}$ \\
\hline Malling I ... . & $\begin{array}{l}\text { medium } \\
\text { many }\end{array}$ & $\begin{array}{l}\text { medium and } \\
\text { large }\end{array}$ & medium & large \\
\hline Malling II. . & medium & $\begin{array}{l}\text { large and } \\
\text { medium }\end{array}$ & $\begin{array}{l}\text { medium to } \\
\text { deep }\end{array}$ & $\begin{array}{l}\text { fair to } \\
\text { sinall }\end{array}$ \\
\hline Malling XII. & $\begin{array}{l}\text { many to } \\
\text { very many }\end{array}$ & $\begin{array}{l}\text { large and } \\
\text { medium }\end{array}$ & deep & $\begin{array}{l}\text { small to } \\
\text { fair }\end{array}$ \\
\hline Malling XVI. & many & $\begin{array}{l}\text { medium and } \\
\text { large }\end{array}$ & $\begin{array}{l}\text { deep to } \\
\text { medium }\end{array}$ & $\begin{array}{l}\text { fair to } \\
\text { medium }\end{array}$ \\
\hline Beautiful Arcade.... & many & $\begin{array}{l}\text { large and } \\
\text { medium }\end{array}$ & deep & fair \\
\hline Melba.... & $\begin{array}{l}\text { many to } \\
\text { medium }\end{array}$ & $\begin{array}{l}\text { medium and } \\
\text { large }\end{array}$ & $\begin{array}{l}\text { nedium to } \\
\text { deep }\end{array}$ & sinall \\
\hline Yellow Transparent. & $\begin{array}{l}\text { many to } \\
\text { medium }\end{array}$ & $\begin{array}{l}\text { medium and } \\
\text { large }\end{array}$ & $\begin{array}{l}\text { medium to } \\
\text { deep }\end{array}$ & small \\
\hline
\end{tabular}

* In the descriptions the emphasis is always on the first word, e.g., roots described as deep to medium are deeper than those described as medium to deep. 


\section{Hardiness of Rootstocks}

During the 20-year period covered by the experiments which have been described, there were two exceptionally cold winters, 1935-36 and 1949-50. At the Summerland Station the minimum temperatures were $-16^{\circ} \mathrm{F}$. and $-22^{\circ} \mathrm{F}$. respectively. On both occasions there was moderate snow coverage in the orchards, rarying from 6 to 18 inches. Under these conditions there was no apparent injury to any of the rootstocks included in the experiments. Consequently there was no opportunity to evaluate their relative hardiness.

A test under more severe conditions, and including a wider range of rootstocks, was conducted in growers' orchards in the Kamloops, Salmon Arm and Vernon districts. These plantings, many of which were combined with tests of hardy frameworks, were made in 1939, 1940 and 1941. The rootstocks tested were seedlings of Anis, Antonovka, Canada Baldwin, Columbia Crab, Duchess, French Crab, Malus baccata, Martha Crab, McIntosh, Wealthy and Yellow Transparent, and the clonal stocks Malling I, II, IX and XVI. In the serere winter of 1949-50 temperatures of $-30^{\circ} \mathrm{F}$. to $-35^{\circ} \mathrm{F}$. were experienced in each of these districts. There was, however, a heavy snow coverage on the ground during the cold weather and, under these conditions, none of the rootstocks showed injury.

\section{DISCUSSION}

The commercial apple nurseries of North America have, in general, been operated on a basis of seedling rootstocks. In British Columbia most nurseries still operate on this basis and there is no indication that any widespread change towards clonal rootstocks is in sight. Seedling rootstocks have proved generally satisfactory in producing orchards of reasonable uniformity in size of tree and in crop, of high vigor, of good average resistance to disease and of long life. Seedlings are relatively cheap to produce when compared with clonal stocks, and dependable sources of supply are rearily available.

On the other hand, the increasing cost of producing apples, and the increasing difficulty of obtaining skilled labor to operate orchards of large trees, has compelled many growers to consider a smaller type of tree. The use of clonal rootstocks offers a means of obtaining trees of the desired smaller size.

Nurseries which have engaged in the propagation of trees on clonal roots have experienced difficulty in growing their trees at a price attractive to the grower, and the future use of such stocks would appear to be partly a matter of economics as between the nurseryman and the grower.

The results of this Station's work indicate that growers desiring a tree of full standard size, to be spaced $30^{\prime}$ to $40^{\prime}$, would be well advised to use a seedling rootstock, giving preference to Antonovka seedlings if available. Any advantage in possible increased uniformity of full sized trees by the use of Malling XVI rootstock does not appear to justify the higher cost of producing trees on this stock.

If a grower desires an orchard of somewhat smaller than standard sized trees, requiring a minimum spacing of $25^{\prime} \times 25^{\prime}$, he is advised to use Malling II. If a still smaller tree, requiring a spacing of about $16^{\prime} \times 16^{\prime}$ is desired, a Malling VII rootstock may perhaps be considered. An orchard of true dwarf trees, spaced about $8^{\prime} \times 15^{\prime}$ and requiring mechanical support, can be secured by the use of Malling IX rootstock. 


\section{ACKNOWLEDGMENTS}

Acknowledgment is due to the late R. C. Palmer, Superintendent of the Dominion Experimental Station, Summerland, B.C., who imported the first Malling rootstocks and who originated these experiments. Thanks are also extended to the Laboratory of Plant Pathology, Summerland, for conducting the crown rot inoculation tests. The photographs in this bulletin are the work of J. E. Britton.

\section{REFERENCES}

1. Bane, W. A., F. H. Beard and A. F. de Wet. A comparison of the root-systems of mature trees of Bramley's Seedling and Worcester Pearmain on various rootstocks. Ann. Rept. East Malling Res. Stat. 1934, pp. 90-99. 1935.

2. Brase, K. D. Development of smaller-than-standard trees for commercial orcharding with particular reference to dwarfing or size-controlling rootstocks. $69 \mathrm{Ann}$. Rept. N.Y. State Agr. Exp. Stat. 1950.

3. Davis, M. B., D. S. Blair and H. B. Cannon. Apple rootstock studies. Division of Hort. Exp. Farms Service. Progr. Rept. 1934-1948, p. 11.

4. Hilborn, M. T. and J. H. Waring. A summary of investigations on the use of hardy trunk-forming stocks in Maine. Proc. Amer. Soc. Hort. Sci. 48: 151-165. 1946.

5. Hoblyn, T. N. Research on fruit tree rootstocks. Ann. Rept. East Malling Ress. Stal. 1950, pp. 193-200. 1951.

6. Kelsall, A. Some apple stocks at the Kentville Station. 83 Ann. Rept. Nora scolia Fruit Grower's' Assn. 1946, pp. 51-54.

7. Mann, A. J., and F. W. L. Keane. Root and framework stocks for fruit trees. Dom. Exp. Stat., Summerland. Progr. Rept. 1937-1948, pp, 23-32. 1951.

8. Nelson, S. H., and W. R. Phillips. Rootstock investigations with regard to the storage quality of fruit. Departmental Paper, Division of Horticulture, Central Experimental Farm, Ottawa. 1951.

9. Shaw, J. K. The anchorage of clonal stock apple trees. Proc. Amer. Soc. Hort. Sci. 48: 166-170. 1946.

10. Shaw, J. K. The influence of Malling clonal stocks on the growth of certain apple varieties. Proc. Amer. Soc. Hort. Sci. 48: 171-179. 1946.

11. Snedecor, G. W. Statistical methods. Collegiate Press Inc., Ames, Iowa. 1938.

12. Sudds, R. H. The effect of Malling I, II and XIII rootstocks on several apple varieties. Proc. Amer. Soc. Hort. Sci. 46: 227-229. 1945.

13. Tukey, H. B. Rootstocks for the apple and the pear in America. The Fruit Year Book. 1951-52, pp. 19-26.

14. Upshall, W. H. Malling stocks and French Crab seedlings as stocks for five varieties of apples. Sci. Agr. 28: 454-460. 1948.

15. Yerkes, G. E., and R. H. Sudds. The effect of the stocks on seven year's growth of four apple yarieties. Proc. Amer. Soc. Hort. Sci. 37: 294-298. 1939. 
EDMOND CLOUTIER, C.M.G., O.A., D.S.P

QUEEN'S PRINTER AND CONTROLLER OF STATIONERY OTTAWA, 1954 